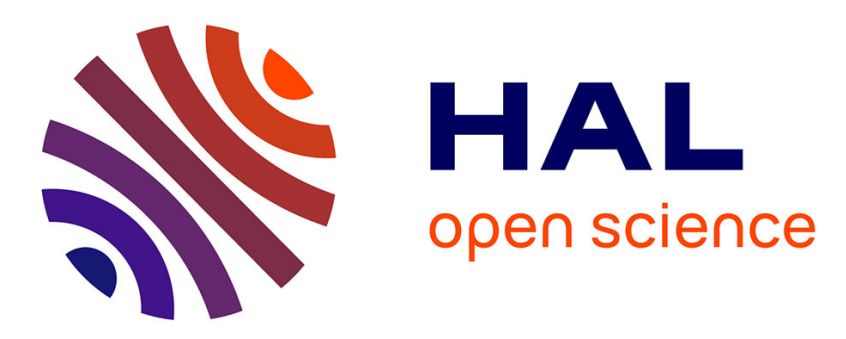

\title{
Climate change threatens the most biodiverse regions of Mexico
}

\author{
Manuel Esperon-Rodriguez, Linda Beaumont, Jonathan Roger Michel Henri \\ Lenoir, John Baumgartner, Jennifer Mcgowan, Alexander Correa-Metrio, \\ James Camac
}

\section{To cite this version:}

Manuel Esperon-Rodriguez, Linda Beaumont, Jonathan Roger Michel Henri Lenoir, John Baumgartner, Jennifer Mcgowan, et al. Climate change threatens the most biodiverse regions of Mexico. Biological Conservation, 2019, 240, pp.108215. 10.1016/j.biocon.2019.108215 . hal-02357035

\section{HAL Id: hal-02357035 https://hal.science/hal-02357035}

Submitted on 9 Nov 2019

HAL is a multi-disciplinary open access archive for the deposit and dissemination of scientific research documents, whether they are published or not. The documents may come from teaching and research institutions in France or abroad, or from public or private research centers.
L'archive ouverte pluridisciplinaire HAL, est destinée au dépôt et à la diffusion de documents scientifiques de niveau recherche, publiés ou non, émanant des établissements d'enseignement et de recherche français ou étrangers, des laboratoires publics ou privés. 


\section{Climate change threatens the most biodiverse regions of Mexico}

Manuel Esperon-Rodriguez ${ }^{1^{\star}}$, Linda J Beaumont ${ }^{2}$, Jonathan Lenoir ${ }^{3}$, John B Baumgartner ${ }^{2}$, Jennifer McGowann ${ }^{2,4}$, Alexander Correa-Metrio ${ }^{5}$, James S Camac ${ }^{6}$

${ }^{1}$ Hawkesbury Institute for the Environment, Western Sydney University, Locked Bag 1797, Penrith NSW 2751 Australia

2 Department of Biological Sciences, Macquarie University North Ryde, NSW, Australia

3 UR 'Ecologie et Dynamique des Systèmes Anthropisés' (EDYSAN, UMR 7058 CNRS-UPJV), Université de Picardie Jules Verne, Amiens, France

${ }^{4}$ Australian Research Council Centre of Excellence for Environmental Decisions The University of Queensland St Lucia Australia

${ }^{5}$ Instituto de Geología, Universidad Nacional Autónoma de México, Coyoacán 04510, Mexico City, Mexico.

${ }^{6}$ Centre of Excellence for Biosecurity Risk Analysis (CEBRA), School of BioSciences, University of Melbourne, Parkville, Victoria, Australia

${ }^{*}$ Corresponding author m.esperon-rodriguez@westernsydney.edu.au Hawkesbury Institute for the Environment Western Sydney University. Richmond, NSW 2753, Australia 


\section{AUTHOR CONTRIBUTIONS}

MER: design of the research; performance of the research; data analysis, collection, and interpretation; writing the manuscript

LJB: performance of the research; data interpretation; writing the manuscript

$\mathrm{JL}$ : performance of the research; data interpretation; writing the manuscript

JBB: design of the research; performance of the research; data interpretation; editing the manuscript

JM: performance of the research; expertise advice on methods; editing the manuscript

ACM: design of the research; expertise advice on methods; editing the manuscript JSC: performance of the research; expertise advice on methods; editing the manuscript 


\section{Climate change threatens the most biodiverse regions of Mexico}

GRAPHICAL ABSTRACT

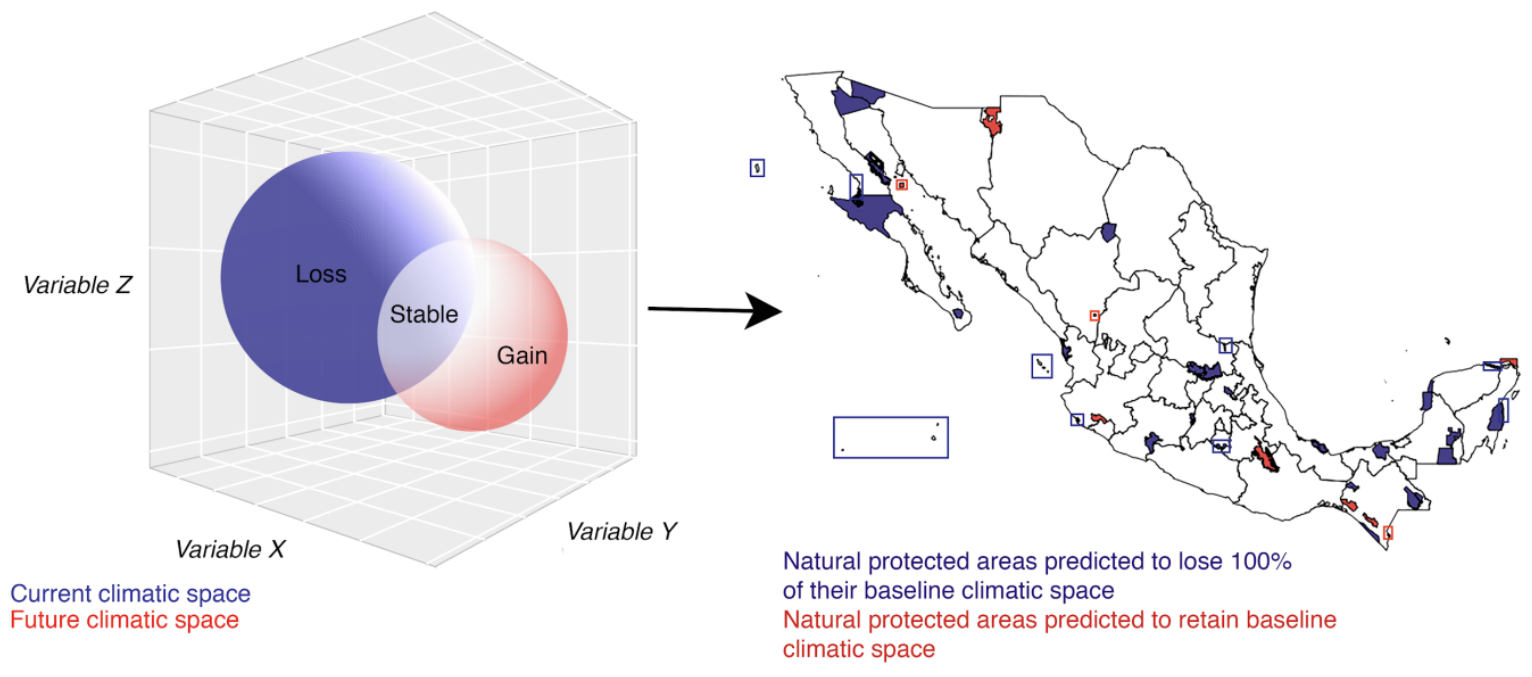




\section{ABSTRACT}

2 Climate change threatens Earth's biodiversity, although its impacts are variable

3 and depend on the capacity of species and ecosystems to cope with the magnitude

4 and speed of change. Natural protected areas (NPAs) constitute potential refugia

5 for species' persistence and for sustaining the provisioning of ecosystem services.

6 Biosphere reserves are NPAs that are less altered by human actions and provide

7 habitat to endemic, threatened or endangered species. Here, we aim to evaluate

8 the threat imposed by climate change on the network of biosphere reserves in

9 Mexico. Focusing on five bioclimatic variables, we computed the climatic space -

10 measured as an $n$-dimensional hypervolume - of 40 NPAs. Increases in

11 temperature are predicted for all NPAs by 2050, whereas decreases in annual

12 rainfall are predicted for 30 NPAs. By 2050, 31 NPAs that provide habitat to 22,866

13 recorded species are predicted to lose $100 \%$ of their baseline climatic space,

14 shifting to completely novel climates. On average, the other nine NPAs are

15 predicted to lose $55.7 \%(S D=26.7 \%)$ of their baseline climatic space, while $54.5 \%$

$16 \quad(S D=32.5 \%)$ of the future climatic space will be novel. Seventeen NPAs may lose

17 climate variability (homogenization), decreasing species' niches. The extent to

18 which non-analogue conditions will remain within the tolerance of species and

19 ecosystems is currently unknown. Finally, we propose a vulnerability index to

20 categorise NPAs based on their loss of existing climatic space, total geographic

21 area, species richness, and uniqueness of species composition, finding los Tuxtlas

22 and Tiburon Ballena as the most and least vulnerable NPAs, respectively.

23 Key words: Biosphere reserves; climatic space; climate niche; hypervolume;

24 natural protected areas; vulnerability 


\section{HIGHLIGHTS}

26 - Across 40 protected areas, temperature is predicted to increase $\sim 3^{\circ} \mathrm{C}$ by

$27 \quad 2050$

28 - 31 protected areas are predicted to lose $100 \%$ of their baseline climatic

29 space

30 - 17 protected areas may lose climate variability (homogenization),

31 decreasing species' niches

32 - The effect of non-analogue conditions on species and ecosystems is largely

33 unknown

34 - We propose a vulnerability index to categorise natural protected areas 


\section{INTRODUCTION}

36 Rapid modern climate change is already altering species distributions and

37 reorganising the composition of many ecosystems (Lenoir and Svenning 2015).

38 These changes have important direct and indirect consequences on ecosystem

39 functioning, human health, and climatic feedbacks (Bonebrake et al. 2018; Pecl et

40 al. 2017; Scheffers et al. 2016). Thus, projected increases in temperature, shifts in

41 precipitation patterns, and the increasing occurrence of extreme weather events

42 jeopardize the persistence of ecosystems and the species they support (Field et al.

43 2014).

$44 \quad$ Effective conservation and management practices depend strongly on our

45 ability to predict the impacts of climate change on natural and human-managed ecosystems (Mawdsley et al. 2009). However, predicting the impacts of climate

47 change is particularly challenging, due to the complexities of climatic processes

48 and uncertainty about the rate and magnitude of changes (Baumgartner et al.

49 2018; Beaumont et al. 2019; Fatichi et al. 2016; Grierson et al. 2011; Loarie et al.

50 2009; Ohlemüller 2011). As changes in climate intensify, assessments of the

51 extent to which the available climatic space may change are particularly important

52 in order to identify species most threatened by changing climate (Guisan et al.

53 2014). relatively stable climate, referred to as refugia (or microrefugia). These areas apparently retained local environmental conditions suitable for species persistence,

57 amidst regionally unsuitable conditions (Correa-Metrio et al. 2014; Médail and 
areas fostering endemic biodiversity (Harrison and Noss 2017). Although the

60 concept of refugia has been more commonly applied to historical periods during

61 the Quaternary, the idea that some areas may act as potential refugia (or

62 microrefugia) under contemporary and future anthropogenic climate change is now

63 widely accepted by the scientific community (Hannah et al. 2014; Keppel et al.

64 2012; Keppel and Wardell-Johnson 2015). Hence, maintaining a functional network

65 of protected areas that retain a sufficient proportion of their existing climatic space

66 into the future will limit biodiversity losses associated with rapid climate change,

67 promote the delivery of ecosystem services, provide livelihoods, and sustain local

68 communities (Ervin 2003; IUCN 2005).

69 Mexico is a megadiverse country harbouring almost $10 \%$ of the world's

70 biodiversity (Challenger 1998; Mittermeier et al. 1998; Sarukhán Kermez and Dirzo

71 1992). Currently, the Mexican natural protected areas (NPAs), administered by the

72 National Commission of Natural Protected Areas (Comisión Nacional de Áreas

73 Naturales Protegidas; CONANP), cover more than 25.3 million hectares (Vargas

74 Márquez et al. 2011). Such a large network has the potential to provide refugial

75 capacity (sensu Keppel and Wardell-Johnson 2015) for ecosystems and adjacent

76 areas, facilitating the maintenance of populations, water quality, nutrient cycling,

77 and ecological flows (DeFries et al. 2010). These NPAs provide habitat for species

78 considered endemic, threatened, or endangered (Batisse 1982; Ishwaran et al.

79 2008). Because of the significance of these NPAs, we highlight the importance of

80 understanding the exposure of these ecosystems and the species they harbour to

81 risks associated with future climate change. This understanding is essential for

82 developing and designing effective management and conservation programs (Cash 
83 and Moser 2000). Such a task, in turn, requires the use of approaches and tools

84 that can be applied to species, taxonomic groups, and regions to propose and

85 design a climate-ready protected area network (Graham et al. 2019). One such

86 approach is an assessment of the climatic space that is currently available and

87 how this may be altered by modern rapid climate change.

Here, we evaluate the magnitude of climate change to which species and ecosystems in 40 of Mexico's NPAs will be exposed by 2050 . Specifically, we ask three questions: (1) How does climatic space differ across the 40 Mexican NPAs

91 included in this study? (2) How much of the existing climatic space will be retained

92 in the near future (2050)? and (3) Which protected areas are most vulnerable to 93 climate change?

\section{METHODS}

96 Natural protected areas (NPAs)

97 Here, we provide a case study of the risks associated with climate change for 40 of

98 Mexico's 174 NPAs, administered by the federal government (CONANP). The 40

99 NPAs form part of the UNESCO's World Network of Biosphere Reserves and were

100 designed to preserve goods and services provided by the ecosystems they

101 harbour. Six of these NPAs have been named World Heritage Centres as natural

102 assets: (1) Sian Ka'an (Quintana Roo); (2) El Vizcaíno (Baja California Sur); (3)

103 Alto Golfo de California y Delta del río Colorado (Baja California-Sonora); (4) the

104 Mariposa Monarca reserve (Mexico-Michoacan); (5) El Pinacate y Gran Desierto

105 de Altar (Sonora); and (6) Archipelago of Revillagigedo (Colima) (CONANP 2006;

106 UNESCO 2017; Villalobos 2000) (Figure 1). Combined, the 40 NPAs cover $\sim 12.5$ 
107 million ha ( $50 \%$ of the total area of NPAs in Mexico), and are representative of

108 ecosystems that need to be preserved and restored (CONANP 2006). We

109 extracted the boundaries for the 40 NPAs from the 2010 CONABIO shapefile

110 (Bezaury-Creel et al. 2009).

111

112 Figure 1. Location of the 40 protected areas of Mexico: 1) Alto Golfo de California y delta

113 del río Colorado; 2) El Pinacate y Gran Desierto de Altar; 3) Janos; 4) Isla Guadalupe; 5)

114 Bahia de los Angeles, canales de Ballenas y de Salsipuedes; 6) Isla San Pedro Mártir; 7)

115 Complejo lagunar Ojo de Liebre; 8) El Vizcaíno; 9) Mapimí; 10) Sierra de la Laguna; 11)

116 La Michilía; 12) Archipielago de Revillagigedo; 13) Islas Marias; 14) Marismas

117 Nacionales; 15) Sierra del Abra-Tanchipa; 16) Sierra Gorda de Guanajuato; 17) Sierra

118 Gorda; 18) Barranca de Metztitlán; 19) Chamela-Cuixmala; 20) Sierra de Manantlán; 21)

119 Zicuirán Infiernillo; 22) Mariposa Monarca; 23) Sierra de Huautla; 24) Tehuacán-Cuicatlán;

120 25) Los Tuxtlas; 26) Pantanos de Centla; 27) Los Petenes; 28) Ría Celestún; 29) Ría 
121 Lagartos; 30) Tiburón Ballena; 31) Sian Ka'an; 32) Arrecifes de Sian Ka'an; 33) Calakmul;

122 34) Lacan-Tún; 35) Montes Azules; 36) Volcán Tacaná; 37) El Triunfo; 38) La Encrucijada;

123 39) Selva el Ocote; and 40) La Sepultura.

125 Climate data

126 For both the baseline and future climate data across the 40 NPAs, we downloaded

127 the set of 19 bioclimatic variables at a spatial resolution of 30 arc-seconds $(\sim 1 \mathrm{~km}$

128 at the equator) from WorldClim (Version 1.4) (http://www.worldclim.org/). Data

129 were projected to the INEGI Lambert Conformal Conic equal area projection

130 (EPSG:6362) with $1 \times 1 \mathrm{~km}$ resolution. Baseline data represent climate conditions

131 during the period 1960-1990. For future climate data, we downloaded projections

132 of four Global Climate Models (GCMs) recommended for Mexico (Cavazos et al.

133 2013; Fernández Eguiarte et al. 2015): (1) MPI-ESM-LR (Germany); (2) GFDL-

134 CM3 (USA); (3) HADGEM2-ED (United Kingdom); and (4) CNRM (France). For

135 these four GCMs, we used the Representative Concentration Pathway (RCP) 8.5,

136 which projects emissions to continue to rise throughout the 21st century

137 (Meinshausen et al. 2011). Following the precautionary principle of risk

138 assessment, we chose a high-emission scenario in order to investigate the

139 maximum change that can be expected for climate and to maximize the impact of

$140 \mathrm{CO}_{2}$ concentration change and $\mathrm{CO}_{2}$-related climate change on vegetation ( $\mathrm{Yu}$ and

141 Wang 2014). Additionally, this scenario is often used to assess risks and possible

142 costs associated with climate change (Riahi et al. 2011). We selected data for

1432050 (average for 2041-2060), aiming to explore a future scenario that matches

144 the short-term timeframe of current management and conservation practices. 
145 Extrapolating our results to a more distant future (e.g. 2070) would increase 146 uncertainty.

147 We evaluated correlations among the 19 bioclimatic variables using

148 Pearson's product-moment correlation (Legendre and Legendre 2012) (Appendix

149 1). Out of the highly correlated pairs $(|r|>0.7)$, we selected one of the covariates

150 based on biological relevance. We retained a subset of nine uncorrelated

151 bioclimatic variables. We then performed a principal component analysis (PCA) on

152 baseline data and based on the magnitude and direction of the vectors (i.e.

153 bioclimatic variables) in relation to main principal components (i.e. first two PC

154 axes) and biological relevance, we selected a final set of five bioclimatic variables

155 to perform our subsequent analyses: (1) Max Temperature of the Warmest Month

156 (BIO5; MTWM); (2) Min Temperature of the Coldest Month (BIO6; MTCM); (3)

157 Temperature Annual Range (BIO7; TAN); (4) Annual Precipitation (BIO12; AP);

158 and (5) Precipitation Seasonality (BIO15; PS). This additional reduction in the

159 number of variables was necessary to reduce computational demand associated

160 with calculating hypervolumes (see details below).

161 Maximum and minimum temperature (MTWM, MTCM) are useful to examine

162 how species distributions are affected by warm and cold temperature anomalies

163 throughout the year. The temperature annual range (TAN) is useful when

164 examining whether species' distributions are affected by ranges of extreme

165 temperature conditions (O'Donnell and Ignizio 2012). Evidence suggests that

166 increases in temperature might affect species' ranges, ecological interactions, and

167 even survival of populations (Allen et al. 2010; Field et al. 2014; Thomas et al.

168 2004; Walther et al. 2002). Annual precipitation ( $A P)$ affects ecosystems 
169 differentially and plays a key role in determining species' distributions (Moles et al.

170 2014; O'Donnell and Ignizio 2012; Weltzin et al. 2003). The predicted changes in

171 precipitation patterns and total rainfall represent a risk to both species and

172 ecosystems (Anderegg et al. 2015; Field et al. 2014). Precipitation seasonality (PS)

173 is a measure of the variation in precipitation throughout the year, with higher values

174 indicating higher variability (O'Donnell and Ignizio 2012), and may be important for

175 species dependent on seasonal patterns of rainfall. The values of these five

176 variables were extracted for each NPA using a $1 \times 1 \mathrm{~km}$ grid, yielding baseline and

177 future scenarios comprising the average of future projections from the four GCMs.

178 Baseline and future scenarios for each NPA were characterized in terms of the

179 mean, standard deviation, and range of the five variables across all grid cells

180 occurring within a given NPA. The magnitude of climate change in the NPAs was

181 then assessed by estimating the absolute difference between baseline and future

182 values (mean, standard deviation, and range) of each variable.

184 Climatic space

185 We considered the climatic space as a 5-dimensional hypervolume (sensu

186 Hutchinson 1957), constructed with the five aforementioned bioclimatic variables.

187 These variables represent and quantify variation in climatic conditions across a

188 given NPA. We extracted values of the five bioclimatic variables from the cells

189 contained within each NPA. These data were standardized to have zero mean and

190 unit variance before constructing baseline and future hypervolumes. The units of

191 the hypervolumes are, therefore, given in standard deviations (SDs) (for a detailed

192 derivation of data preparation, see Blonder et al. 2014). 
To quantify the climatic space, we used the package hypervolume (version

194 2.0.11) (Blonder and Harris 2018) in R (version 3.4.4) (R Core Team 2018). Default

195 settings were used to estimate hypervolumes with the Gaussian kernel density

196 estimate method and the Silverman estimator for bandwidth selection. Specifically,

197 we used the function <hypervolume_overlap_statistics> to compare baseline and

198 future climatic space. This function provides a set of metrics: (1) unique fraction 1

199 (volume of the unique component of the baseline climatic space divided by the total

200 volume of the baseline climatic space); and (2) unique fraction 2 (volume of the

201 unique component of the future climatic space divided by the total volume of the

202 future climatic space) (Blonder and Harris 2018).

203 Using the above metrics, for each NPA, we calculated: (1) the stable

204 climatic space (i.e. 1 - unique fraction 1); (2) the loss of current climatic space

205 (unique fraction 1); and (3) the gain of future climatic space (i.e. unique fraction 2)

206 (Figure 2). Additionally, we identified cases where NPAs were predicted to

207 undergo increases or decreases to the overall volume of climatic space available.

208 An increase in hypervolume represents a gain in climate variability, while a

209 decrease indicates a more homogenous future climate. 

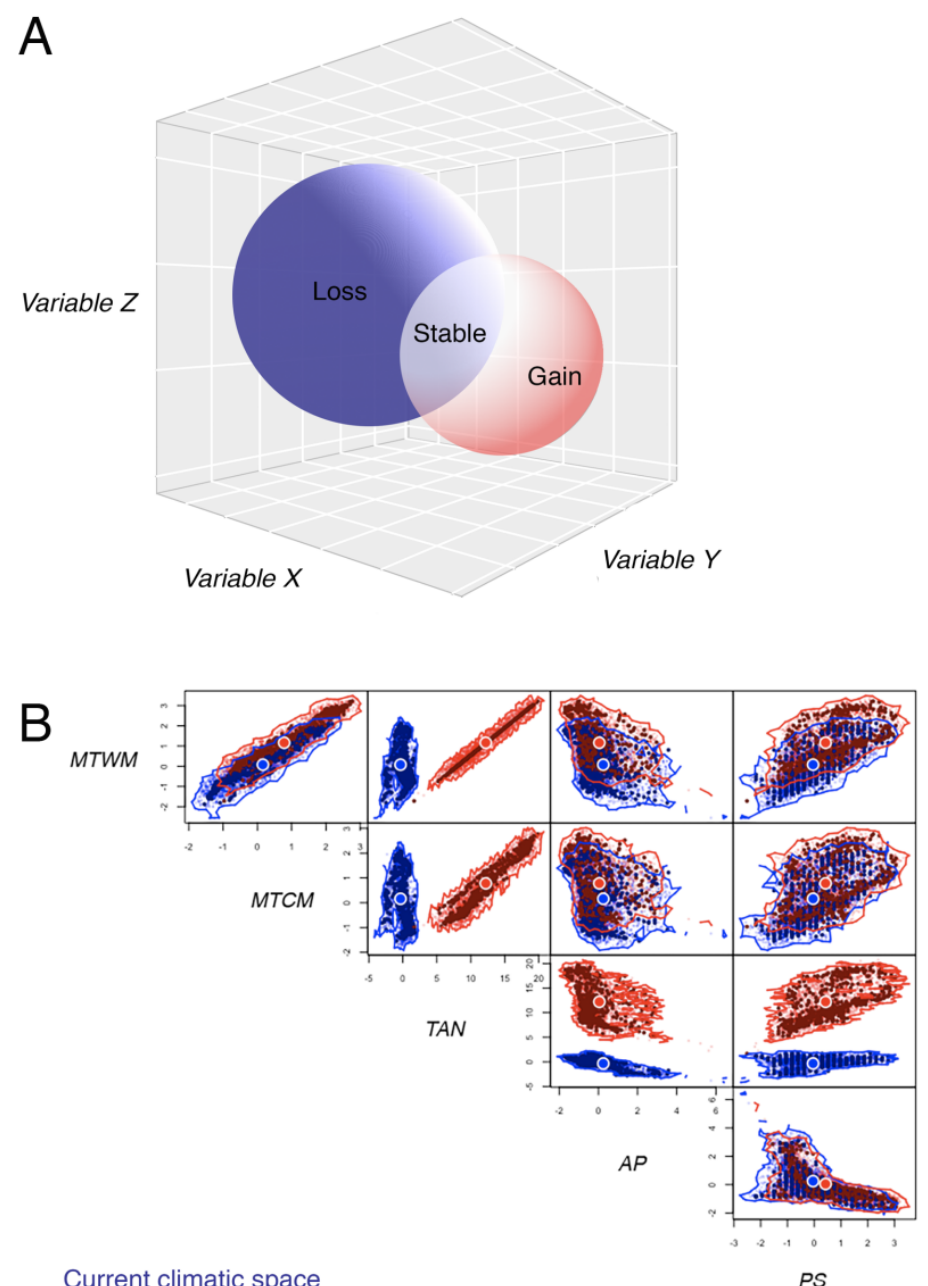

Future climatic space

211 Figure 2. (A) Schematic figure to illustrate the concept of climatic space or hypervolume

212 for baseline (blue; 1960-1990) and future (red; 2050, average for 2041-2060) conditions in

213 a given protected area. We estimated: (1) the stable climatic space (i.e. intersection of

214 baseline and future climatic spaces, as a proportion of the baseline hypervolume); (2) the

215 loss of climatic space (i.e. proportion of baseline climatic space that is no longer

216 represented in the future); and (3) the gain of novel climatic space (i.e. the proportion of

217 future climatic space that was not represented under current climate). (B) Climatic space

218 showing the interactions of five bioclimatic variables: (1) Max Temperature of Warmest

219 Month (MTWM); (2) Min Temperature of Coldest Month (MTCM); (3) Temperature Annual

220 Range (TAN); (4) Annual Precipitation (AP); and (5) Precipitation Seasonality (PS). Here, 
221 we assessed the shift from baseline (blue) to future (red) climatic space for the protected

222 area of Tehuacan-Cuicatlan, Puebla-Oaxaca. For this protected area, the predicted

223 percentages of stable climate, climate loss and climate gain are $\sim 44 \%, \sim 55.7 \%$ and

$224 \sim 56.6 \%$, respectively. Axes are given in units of standard deviations (SDs) of baseline

225 values.

226

227 Vulnerability of natural protected areas to climate change

228 To assess potential vulnerability to climate change, we developed a vulnerability

229 index (modified from Esperón-Rodríguez and Barradas 2015a) that considers three

230 components: (1) the loss of current climatic space, i.e. loss of current climatic

231 space calculated from unique fraction 1 (climatic space loss; CSL); (2) total

232 geographic area (TA); and (3) number of species (species richness, $S R$, see next

233 section). We considered NPAs to be more vulnerable if they had a high loss of

234 current climatic space and have relatively small total area, with a greater impact for

235 a higher number of species (see below). This is a comparative vulnerability index

236 (V) among NPAs, where the highest vulnerability corresponds to 1 and the lowest

237 to 0 , and is estimated for the ith NPA as:

238

$$
V_{i}=\left(V_{\mathrm{CSL}}+V_{\mathrm{TA}}+V_{\mathrm{SR}}\right) / 3
$$

241 The loss of baseline climate $\left(V_{\mathrm{CSL}}\right)$ is obtained by dividing the analogue

242 climatic loss for the ith NPA $\left(\mathrm{CSL}_{i}\right)$ by the highest analogue climatic loss among all

$243 \quad$ NPAs $\left(C S L_{\text {MAX }}\right)$ : 


$$
V_{\mathrm{CSL}}=\left(C S L_{i} / C S L_{\mathrm{MAX}}\right)
$$

The vulnerability component for total area $\left(V_{\mathrm{TA}}\right)$ was obtained by dividing the 248 total area of the ith NPA $\left(T A_{i}\right)$ by the area of the largest NPA (TA $\left.A_{\text {MAX }}\right)$ :

$$
V_{\mathrm{TA}}=1-\left(T A_{i} / T A_{\mathrm{MAX}}\right)
$$

253 was obtained by dividing the total number of species reported in the ith NPA $\left(S R_{i}\right)$

254 by the greatest number of species within an NPA ( $\left.S R_{\mathrm{MAX}}\right)$ :

$$
V_{\mathrm{SR}}=\left(S R_{i} / S R_{\mathrm{MAX}}\right)
$$

NPAs were then ranked from high $(V=1)$ to low $(V=0)$ overall vulnerability.

259 Additionally, we identified the uniqueness of species composition across the 40

260 NPAs (see details below). This information can be used to prioritize management

261 actions under future climate change.

263 Species richness and composition of natural protected areas

264 To assess species richness (SR) and composition at each NPA, we queried the

265 Global Biodiversity Information Facility (January 2019; GBIF, http://www.gbif.org),

266 identifying all species of vascular plants (Tracheophyte), fungi, and animals

267 (amphibians, arthropods, birds, mammals, and reptiles) recorded in each NPA.

268 Occurrence records were downloaded for all of Mexico and then subsetted to 
269 retain only records georeferenced within each NPA. We further restricted records

270 to those with an observational basis reported as "human observation",

271 "observation", "specimen", "living specimen", "literature occurrence", or "material

272 sample".

273 Further, to assess species composition, we developed a species presence-

274 absence matrix for the 40 NPAs. This matrix was then used in a non-metric

275 multidimensional scaling (NMDS) analysis with vegan 2.5-4 (Oksanen et al. 2019)

276 using the square root transformation and calculating the Bray-Curtis distances for

277 our community-by-site matrix in $R$ (version 3.4.4) (R Core Team 2018). NMDS

278 projects multivariate data along latent axes based on distances between

279 assemblages, preserving the underlying dissimilarity structure of the original

280 dataset (McCune et al. 2002). The distance between NPAs in the ordination space

281 reflects the dissimilarity in species composition. Thus, NPAs with similar scores

282 along the axes of the ordinal space are similar in terms of species composition

283 (Legendre and Legendre 2012).

284

285 RESULTS

286 Climate change in the natural protected areas of Mexico

287 Across all NPAs, average conditions for all temperature variables (MTWM, MTCM,

288 TAN) are predicted to increase by 2050 , with the exception of a decrease in TAN at

289 Sierra de la Laguna. On average $( \pm$ SD), MTWM is predicted to increase by $2.8 \pm$

$2900.5^{\circ} \mathrm{C}$, with $M T C M$ and $T A N$ predicted to be $2.1 \pm 0.2^{\circ} \mathrm{C}$ and $0.7 \pm 0.4^{\circ} \mathrm{C}$ warmer

291 relative to baseline climatic averages (1960-1990), respectively. In contrast, annual

292 precipitation $(A P)$ is predicted to decrease in $30 \mathrm{NPAs}$, by $34.4 \pm 32 \mathrm{~mm}$. Only ten 
293 NPAs are predicted to have increases in $A P(16.3 \pm 17.3 \mathrm{~mm})$. Precipitation

294 seasonality is projected to increase by $2.3 \pm 2.9 \%$ by 2050 , although six NPAs are 295 predicted to have declines in PS.

296 For baseline and future conditions, the highest values of MTWM, MTCM,

297 TAN, AP, and PS were found in the Alto Golfo de California, La Encrucijada

298 (Chiapas), Janos (Chihuahua), Montes Azules (Chiapas), and Sierra de la Laguna

299 (Baja California Sur), respectively (Appendix 2). The greatest increases by 2050

300 were predicted in Janos (MTWM and MTCM), La Michilía (Durango, TAN), La

301 Encrucijada $(A P)$, and Ojo de Liebre (Baja California Sur; $P S)$. The smallest

302 increases in temperature were predicted for Sierra de la Laguna (MTCM), Tiburón

303 Ballena (Quintana Roo; MTCM), and Sierra de la Laguna (TAN), while the greatest

304 declines in $A P$ and $P S$ were predicted in Montes Azules $(A P)$ and los Petenes

305 (Campeche; PS) (Appendix 2).

306

307 Climatic space

308 Across all 40 NPAs, the volume of climatic space averaged $89.7( \pm 107.7)$ and

$309120.3( \pm 137.5)$ for the baseline and future time period, respectively, representing

310 greater variability under future conditions relative to baseline. For both time

311 periods, Volcan Tacana (Chiapas) had the broadest climatic space. The narrowest

312 climatic space was found in Calakmul (Campeche) and Sian Ka'an for baseline and

313 future time periods, respectively. Thirty-one NPAs (78\%) were predicted to have no

314 stable climate (i.e. no intersection between the baseline and future climatic space).

315 Hence, these areas are projected to contain completely novel climates by 2050. 
317 remaining stable reached, on average, $48 \%$, ranging from $1 \%$ in Janos to $86 \%$ in

318 La Michilía. Across these NPAs, the average loss of baseline climatic space was

$31955.7 \%( \pm 26.7 \%)$, whereas $54.5 \%( \pm 32.5 \%)$ of future climatic space was novel.

320 The greatest loss of current and gain of novel climatic space were found in Janos

321 (98.8\% and $99.01 \%$, respectively), whereas the lowest loss and gain of climatic

322 space were found in La Michilia (13.9\%) and Tiburon Ballena (4.5\%), respectively

323 (Figure 3; Appendix 3).

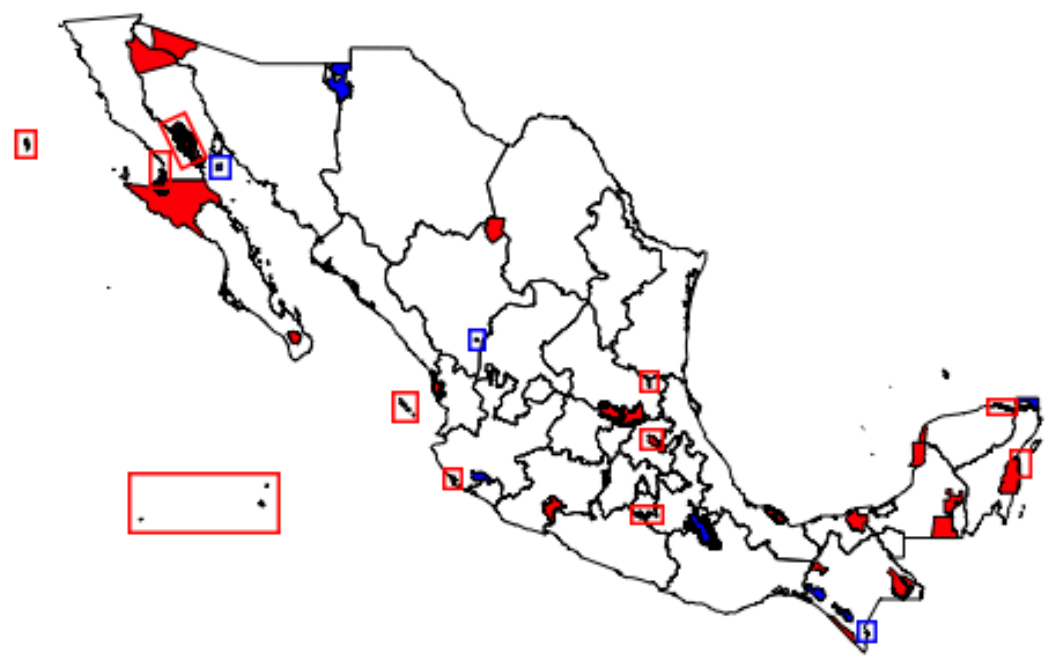

325 Figure 3. Protected areas in red are predicted to have no stable climate (i.e. no

326 intersection between the baseline and future climatic space), hence the whole climatic

327 space by 2050 will be novel. Protected areas in blue are predicted to retain some of their

328 baseline climatic space as well as gain novel climatic space by 2050. See Appendix 3 for

329 details on changes in climatic space and Figure 1 for names of protected areas. 
332 volume of climatic space available (i.e. more homogenous future climate) $(-45.1 \%$

$333 \pm 20.8 \%$, relative to the baseline), with the overall volume predicted to decline by at

334 least 50\% compared to the baseline (Arrecifes de Sian Ka'an [Quintana Roo],

335 Tiburon Ballena, Sian Ka'an, Chamela-Cuixmala [Jalisco], Los Petenes, and La

336 Encrucijada). In contrast, 23 NPAs were predicted to increase their overall volume

337 of climatic space available by $2050(+77.9 \% \pm 55.8 \%$, relative to the baseline $)$, with

338 eight of these NPAs predicted to experience an increase of $>100 \%$ in the overall

339 volume of their climatic space (Figure 4).

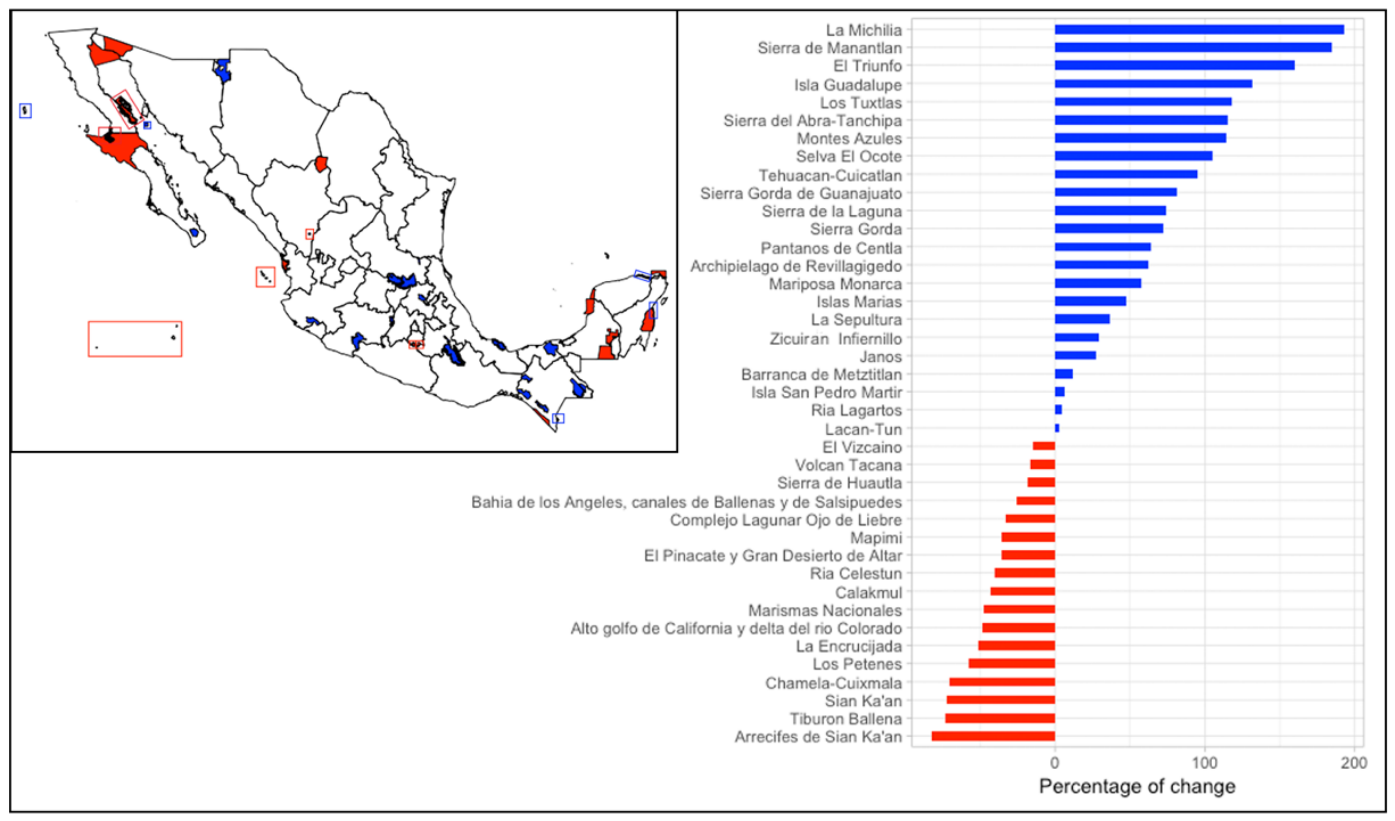

341 Figure 4. Percentage of decreases (red) and increases (blue) to the overall volume of

342 climatic space between baseline (1960-1990) and future (2050, average for 2041-2060)

343 conditions within 40 protected areas, and their location in Mexico (inset map). An increase

344 in volume represents a gain in climate variability, while a decrease indicates a more

345 homogenous future climate. For names of protected areas, see Figure 1. 
Vulnerability of natural protected areas to climate change

348 The average size of the 40 NPAs spans $3127.11 \mathrm{~km}^{2}\left( \pm 4260.7 \mathrm{~km}^{2}\right)$, with the

349 largest being El Vizcaino $\left(24,930.9 \mathrm{~km}^{2}\right)$ while the smallest is Volcan Tacana (63.8

$350 \mathrm{~km}^{2}$ ). The number of species for which there are GBIF records varied across

351 NPAs, with an average of 2147 species ( \pm 1740 species), a maximum of 7524

352 species recorded in Tehuacan-Cuicatlan (Oaxaca, Puebla) and a minimum of 98

353 species recorded in Isla San Pedro Martir (Sonora) (Appendix 4). The mean

354 vulnerability $(V)$ was $0.69( \pm 0.11)$, with a maximum (high vulnerability) of 0.91 at

355 Los Tuxtlas (Veracruz; $1551.22 \mathrm{~km}^{2}$ and 5945 species), and a minimum (low

356 vulnerability) of 0.38 at Tiburon Ballena (1459.9 $\mathrm{km}^{2}$ and 334 species) (Appendix 357 3).

358 Species composition also varied across NPAs (Figure 5), with La Michilia (V

$359=0.40$, ranked 39), Isla Guadalupe (Baja California; $V=0.62$, ranked 32), Isla San

360 Pedro el Martir ( $V=0.48$, ranked 37), and Sierra Abra Tanchipa (San Luis Potosí;

$361 V=0.67$, ranked 27 ) having a relatively different composition of species compared

362 to the other NPAs. The set of NPAs identified to have higher vulnerability (in red

363 and orange in Figure 5) clustered broadly in two geographical groups: (1)

364 mountainous regions of central Mexico (except Sierra de la Laguna) with a more

365 temperate climate and (2) south-east of Mexico in Chiapas and Veracruz (except

366 for Chamela) where the climate is more tropical. 


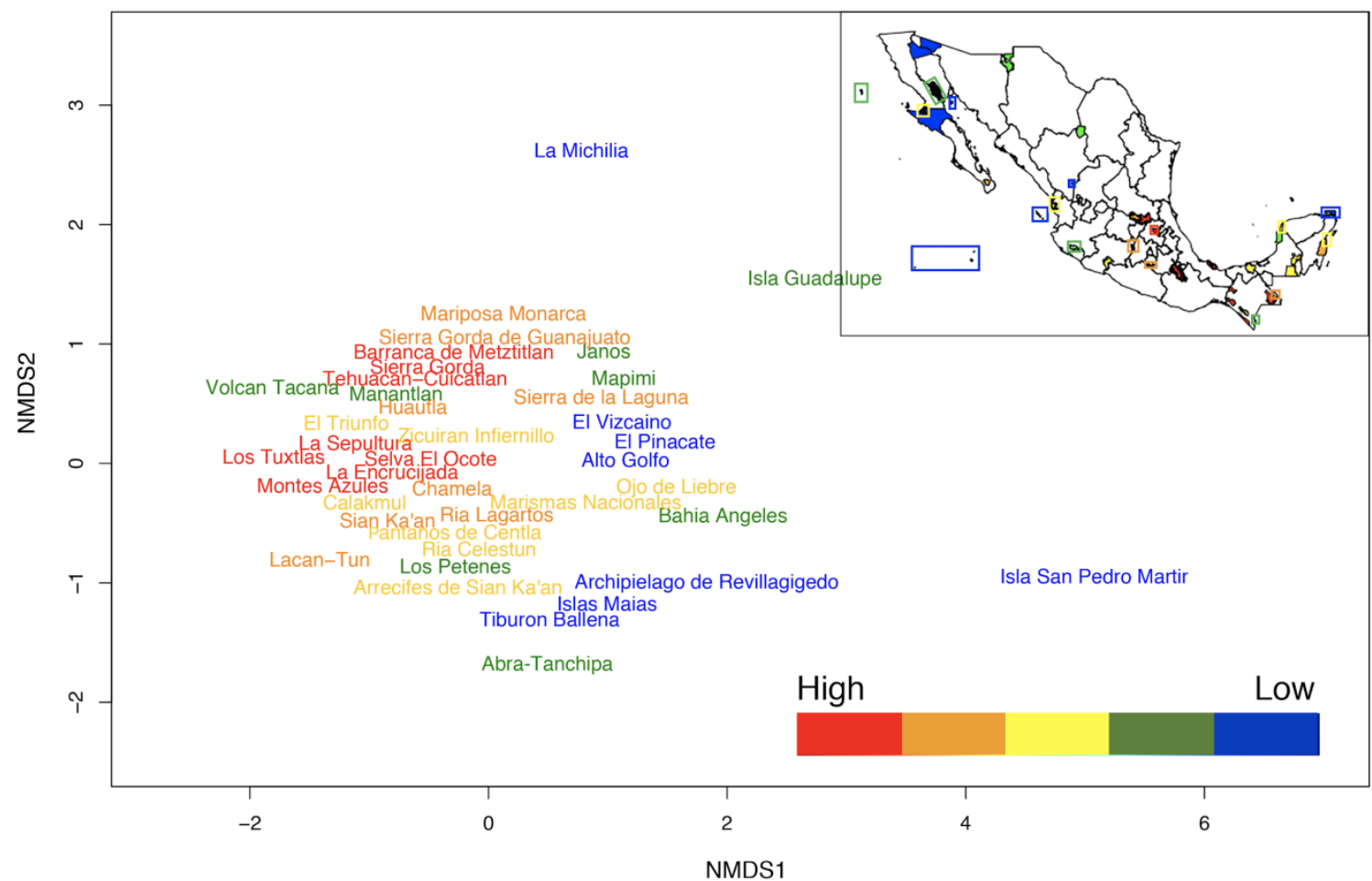

368 Figure 5. Non-metric multidimensional scaling (NMDS) plot for the ordination of the

369 species composition of 40 protected areas and their location in Mexico (inset map).

370 Colours are indicative of vulnerability ranked from high (red) to low (blue). For names of

371 protected areas, see Figure 1.

\section{DISCUSSION}

374 Climate change in natural protected areas of Mexico

375 The predicted increases in temperature, and changes in both total precipitation and

376 precipitation seasonality, will likely affect species' ranges, interactions, and even

377 survival (Allen et al. 2010; Anderegg et al. 2015; Field et al. 2014; Thomas et al.

378 2004; Walther et al. 2002). Within Mexico, temperature is predicted to become

379 warmer across all 40 NPAs by 2050 , with larger increases (up to $3.75^{\circ} \mathrm{C}$ in $\mathrm{MTWM}$ 
and $2.5^{\circ} \mathrm{C}$ in $M T C M$ ) predicted to occur in arid regions that already experience high

381 temperatures (e.g. Janos, Mapimí [Chihuahua, Coahuila, Durango], El Pinacate,

382 and Tehuacán-Cuicatlán). Although the species within these NPAs are adapted to

383 high temperatures, further increases in MTWM and MTCM might represent an

384 additional stress, particularly to those species that are near their upper thermal

385 limits (McCain and Colwell 2011).

386 Rising temperatures in NPAs located in mountainous regions and close to

387 mountaintops are expected to exhibit severe impacts as geographic areas and

388 therefore suitable habitats decrease at higher altitudes, impeding migration of

389 species (Nogués-Bravo et al. 2007). We highlight such a risk at Sierra del Abra-

390 Tanchipa (2477 m asl), Barranca de Metztitlán (Hidalgo, ranging from 1800 - 2600

391 m asl), Sierra Gorda (Queretaro; 1200 - 3000 m asl), Sierra Gorda de Guanajuato

392 (Guanajuato; 900 - 2600 m asl), Sierra de Huautla (Morelos; 1700 m asl),

393 Manantlan (Colima-Jalisco; 400 to $2860 \mathrm{~m}$ asl), Mariposa Monarca (2400 m asl),

394 Tehuacán-Cuicatlán (2950 m asl), and Zicuirán Infiernillo (Michoacan; 1600 m asl).

395 For instance, by 2050, the Mariposa Monarca NPA is predicted to experience an

396 increase in $M T W M$ by $3.5^{\circ} \mathrm{C}$, and although future climatic space may be $>50 \%$

397 broader than the baseline, this will consist of mostly novel conditions. These

398 changes represent a potential risk to the temperate forest that provides habitat to

399 the endangered monarch butterfly (Danaus plexippus), a global flagship species

400 vulnerable to climate change (Lemoine 2015).

401 Decreases in precipitation are predicted in 30 NPAs, while for nine other

402 NPAs, only minor increases in precipitation are likely to occur (i.e. $<22 \mathrm{~mm}$ per

403 year). The largest decreases in annual rainfall are predicted among NPAs where 
404 baseline precipitation is already high (>1000 mm per year). Additionally, 34 of the 40540 NPAs studied here are predicted to experience changes in PS. An increase in 406 PS indicates higher variability of precipitation (O'Donnell and Ignizio 2012),

407 implying increased duration and severity of soil water stress (Knapp et al. 2008).

408 This scenario poses a considerable risk for Sierra de la Laguna, which has the

409 highest $P S$ among the studied areas, and is predicted to experience the largest

410 increases in the same variable by 2050. This NPA provides habitat to at least 1943

411 species. Of these, 86 are endemic plants, including Arbutus peninsularis

412 (Ericaceae), Opuntia lagunae (Cactaceae), and the vulnerable Pinus cembroides

413 ssp. lagunae (Arriaga et al. 2000; Farjon 2013). Importantly, some Pinus species

414 are highly vulnerable to changes in precipitation and have low drought tolerance

415 (Esperón-Rodríguez and Barradas 2015b).

417 Climatic space in Mexico's natural protected areas

418 Here, we assessed the climatic space of 40 NPAs in terms of: (1) stable climatic

419 space into the future; (2) loss of current climatic space; and (3) gain of novel

420 climate by 2050 . We found that 31 NPAs are predicted to retain none of their

421 baseline climatic conditions. Species occurrence from GBIF indicate that these 31

422 NPAs harbour at least 22,866 species of animals, fungi, and vascular plants. The

423 nine NPAs predicted to retain some parts of their baseline climate space by 2050 , 424 and hence may serve as climate refugia, harbour $>14,526$ species. Of these nine

425 NPAs, Janos is predicted to suffer from the highest loss of stable climate

426 (Appendix 3) and also is expected to have the highest increase in temperature 427 conditions (MTWM, MTCM). The fauna of Janos is one of the most varied in North 
America. It maintains the largest breeding population of burrowing owl (Athene cunicularia) and golden eagle (Aquila chrysaetos) in Mexico, as well as the only population of wild bison (Bison bison). This NPA also provides habitat to several

431 endangered species, including the endemic prairie dog (Cynomys mexicanus)

432 (Pacheco et al. 2000).

Along with the threat represented by rising sea levels for islands and coastal

434 NPAs (Mimura 1999; Nicholls and Cazenave 2010), the loss of current climate 435 space is a major concern for the ecosystems they harbor. Except for Isla San

436 Pedro Mártir (stable climate of $\sim 56.7 \%$ ), the other NPAs on islands (Archipelago de 437 Revillagigedo, Isla Guadalupe, and Islas Marias [Nayarit]) are predicted to lose all 438 their baseline climatic space. Islands are highly vulnerable systems as they are 439 geographically confined and, similar to mountaintops, their associated species 440 have limited space to track changes in climate (Mimura et al. 2007). For Isla 441 Guadalupe, for example, the loss of the current climatic space may affect at least 442461 species, including 82 plants and nine bird species endemic to the island. This 443 island is one of the main refugia of marine mammals, such as the northern 444 elephant seal (Mirounga angustirostris) and the Guadalupe fur seal (Arctocephalus 445 townsendi) (Arriaga et al. 2000; Gallo-Reynoso 1994).

446 Twenty-three NPAs are predicted to experience an increase in available 447 climatic space by 2050 , indicating that climatic conditions may be spatially more 448 heterogeneous. However, for 16 of them, future climate will consist of entirely novel 449 climatic conditions, relative to the baseline. Hence, these NPAs have little capacity 450 to function as refugia for the ecosystems they currently shelter. Of higher concern 451 are the 15 NPAs (including all NPAs in the Yucatan Peninsula, except for Tiburon 
Ballena) predicted to lose all their baseline climatic space and also experience

453 substantial decreases in the overall volume of climatic space (Figure 3). A

454 decrease in the volume of climatic space within an NPA represents a loss of

455 climatic variability (i.e. climatic conditions will become spatially more homogenous),

456 and hence a decreasing array of niches that are available, potentially diminishing

457 the refugial capacity of the area. Arrecifes de Sian Ka'an is predicted to suffer from

458 the greatest decrease in climatic volume $(\sim 82 \%)$, in addition to vulnerability to sea

459 level rise, invasive alien species, and growing pressure from tourism (Brenner

460 2010; CONABIO 1995).

461

462 Vulnerability of natural protected areas to climate change

463 A key finding is that the most vulnerable NPAs also share similar biodiversity

464 composition (in red and orange in Figure 5). This result highlights the importance

465 of monitoring and managing these locations and their species with vigilance (Smith

466 et al 2019). Biodiversity loss in these NPAs may be significant if these species

467 prove to be especially vulnerable to climate impacts and prone to local extirpation,

468 and where protection alone will not be sufficient to stop the risk of extinction.

$469 \quad$ Although our index ranks NPAs in terms of their vulnerability, we note that

470 this is a relative index that can only be used to prioritize management and

471 conservation actions within the network of the 40 NPAs assessed here. A low

472 vulnerability score does not mean that an NPA is not vulnerable to climate change

473 per se. Furthermore, some NPAs, such as Isla San Pedro Martir and La Michilia,

474 have relatively low vulnerability rankings $(V=0.48$, ranked 37 of 40 and $V=0.40$,

475 ranked 39 of 40; respectively); however, these NPAs harbor a very unique 
476 composition of species (Figure 5) and are predicted to retain baseline climatic

477 conditions in 2050. These characteristics make these NPAs important potential

478 climate refugia and conservation actions are required to secure the persistence of

479 species and ecosystems in those NPAs.

480

481 What are the caveats and limitations of our study?

482 A series of caveats are associated with our methodology. First, our assessment of

483 the climatic space did not consider other environmental factors that can mitigate or

484 exacerbate the effects of climate change, such as soil type and topography, or the

485 presence/absence of water bodies; furthermore, our approach does not consider

486 the potential feedback mechanisms between climate and biota (e.g. the role of

487 vegetation in modulating temperature). Second, the climate data we used here are

488 based on coarse-grained spatial interpolations from weather stations that are

489 shielded from direct solar radiation and thus fail to account for the microclimate

490 experienced by organisms living in their natural habitats (Lenoir et al. 2017). For

491 instance, our analyses cannot explicitly consider locations where microclimatic

492 conditions are more benign (e.g. protected slopes or areas with high canopy

493 cover). Third, A key source of uncertainty arises from the use of alternative, yet

494 plausible, climate scenarios. By selecting four different GCMs, we aimed to

495 account for the variation among different models in terms of projected temperature

496 and precipitation trends. The selected GCMs have been applied throughout the

497 territory of Mexico and are recommended for impacts assessments (Cavazos et al.

498 2013; Fernández Eguiarte et al. 2015). Nevertheless, we acknowledge that

499 different climate scenarios can produce different results, which might affect 
conservation and management actions (Beaumont et al. 2019; Baumgartner et al.

501 2018; Graham et al. 2019). Further, by selecting the scenario RCP8.5 with the

502 highest radiative forcing and $\mathrm{CO}_{2}$ emissions, our predictions might overestimate

503 the losses of climatic space, in contrast to using a more conservative scenario,

504 such as RCP6.0 (Raftery et al. 2017). Given that our aim is to assess risks, this

505 approach is consistent with the precautionary principle.

506 Another limitation of our approach is that we did not consider the effects of

507 elevated $\mathrm{CO}_{2}$ on photosynthesis and transpiration. The combined effects of the

$508 \mathrm{CO}_{2}$ fertilization effect and climate change can increase plant biomass (Zhu et al.

5092016 ) and affect the performance and functioning of plant species with cascading

510 effects over the biota at each NPA. In NPAs where precipitation is predicted to

511 decrease and temperature to increase, plant phenology may accelerate, reducing

512 dry matter accumulation and altering ecosystem performance (Cao et al. 2010).

513 However, under drought conditions, $\mathrm{CO}_{2}$ fertilization may not counteract the effects

514 of reduced water availability (Temme et al. 2019).

515 We recognize that our assessment of vulnerability only considers the

516 exposure of protected areas to climate change. Species' sensitivity and adaptive

517 capacity were not considered. Individual species respond idiosyncratically to

518 climate change and differ in their capacity to endure its impacts. It is their

519 environmental tolerance, migration ability, and genetic plasticity that facilitate

520 species' resilience to climate change (Esperón-Rodríguez and Barradas 2015b;

521 Lenoir et al. 2008; Pearson 2006; Pellegrini et al. 2017). However, the magnitude

522 of shifts in the climatic space of NPAs might represent a useful general indicator of 523 the potential for negative impacts on resident biota. 
Importantly, our work does not consider additional threats to NPAs. Sea

525 level rise and human impacts such as exploitation and pollution, land-use change

526 and deforestation, may also erode the resilience of NPAs to climate change. In

527 Mexico, deforestation and land-use change are issues of concern (Figueroa and

528 Sánchez-Cordero 2008; SEMARNAT 2015). An example of deforestation is the

529 case of Los Tuxtlas, the most vulnerable NPA $(V=0.91)$, which is predicted to

530 retain only $8.7 \%$ of its natural vegetation in 2020 (Guevara et al. 2004;

531 SEMARNAT 2015).

$532 \quad$ Lastly, we note that our index considers the number of species as a

533 component, and although we collected species records for taxonomic groups with

534 a good representation across NPAs, the sampling effort across NPAs is

535 undoubtedly biased. Therefore, it is highly likely that we have underestimated the

536 number of species occurring within each NPA. Additionally, our species

537 composition analysis might be skewed due to the vastly different numbers of

538 species recorded for these NPAs and represent only an approximation of this

539 composition.

541 Future recommendations

542 Our index can be used to categorise NPAs in terms of their bioregional

543 vulnerability, their capacity to act as potential climatic refugia until 2050 (i.e. retain

544 stable baseline climate), and the number of species that they harbour. This vital

545 information can be used in prioritization frameworks which explicitly consider the

546 benefits, costs, and feasibility of targeted conservation actions (Brown et al. 2015).

547 While some vulnerable species within NPAs likely require immediate conservation 
interventions to mitigate direct impacts, such as the world's most endangered

549 marine mammal, the vaquita (Phocoena sinus) in Alto Golfo de California y Delta

550 del río Colorado (SEMARNAT 2017) whose primary threat is fishing, many other

551 species can benefit from climate-mitigating actions taken in and around NPAs.

552 Prioritizing what actions occur when and where to deliver the largest benefits to the

553 existing NPA network will be a critical next step.

554 Actions that can be prioritized to help climate-proof Mexico's NPA system

555 include the establishment of buffer zones. These zones improve the conservation

556 efficiency of NPAs by promoting ecological flows within areas and increasing the

557 ability of species to shift their distributions as climate changes (Beaumont and

558 Duursma 2012; DeFries et al. 2010), and may help to mitigate losses in the climatic

559 space of the current NPA network assessed here. An additional strategy to

560 attenuate the impacts of climate change is the establishment of biological corridors

561 (Hannah 2008). Habitat connectivity is fundamental to support resilient local

562 populations (Brown and Kodric-Brown 1977). The effects of temperature and

563 moisture on habitat availability and connectivity must remain the main

564 consideration, particularly in fragmented systems such as the Mexican NPA

565 network. Additional considerations include species' dispersal capacities, the

566 accessibility of NPAs and the distance between them, and species' biology and

567 behaviour (Henein and Merriam 1990).

568 In extreme cases where NPAs and additional area-based management (e.g.

569 the establishment of buffer zones and corridors) fail to provide or retain suitable

570 conditions, thereby jeopardizing species survival, species translocation or assisted

571 migration may be necessary (Hoegh-Guldberg et al. 2008). While managed 
572 relocation of species remains a contentious issue, there are quantitative

573 frameworks that could be explored for species with limited dispersal capacities

574 which are found in the more vulnerable NPAs (McDonald-Madden et. al 2011) Yet,

575 consideration must be given to minimise potential risks of invasion in the

576 introduced area when translocating species. Further, the species and locations that

577 will benefit most from translocation have yet to be explored for Mexico's

578 biodiversity.

579 Finally, we highlight that NPAs require continuous monitoring to assess

580 other stressors that might increase their vulnerability. The characteristics of the

581 non-protected areas surrounding NPAs will impact the condition and performance

582 of each NPA. For instance, some of the 40 studied NPAs (e.g. Chamela-Cuixmala,

583 Sierra Gorda de Guanajuato, Tehuacán-Cuicatlán, and Barranca de Metztitlán) are

584 located near heavily populated areas and receive additional stressors including

585 irregular human settlements, hydrometeorological hazards, and floods ( $\mathrm{Cl} 2002$;

586 SEDATU 2017). These stressors will undoubtedly affect habitat suitability and

587 connectivity for species living in these NPAs, and combined with climate change,

588 will exacerbate their vulnerability. The development of an accurate risk assessment

589 with a more detailed analysis of each NPA is required. This assessment must aim

590 at evaluating the magnitude of the impacts of future climate change of the most

591 vulnerable NPAs and identify the species most at risk of extirpation.

592

\section{CONCLUSION}

594 The capacity of Mexico's 40 UNESCO World Network of Biosphere Reserves to 595 function as long-term refugia for biodiversity is likely to decline as the magnitude of 
596 climate change increases. By the mid-century, 31 NPAs, which together provide

597 habitat to at least 22,866 species, are predicted to lose all their baseline climatic

598 space, shifting to novel climates. The extent to which these conditions will be within

599 the tolerance of species and ecosystems is currently unknown.

600

601 SUPPLEMENTARY MATERIAL DESCRIPTION

602 Appendix 1. Pearson correlation of 19 bioclimatic variables.

603 Appendix 2. Changes in climate were assessed by comparing baseline (averages

604 between 1960 and 1990) and future (2050 [average for 2041-2060]; average of

605 four global circulation models) conditions based on five bioclimatic variables.

606 Appendix 3. Changes in climate spaces comparing baseline (averages between

6071960 and 1990) and future (2050 [average for 2041-2060]; average of four global

608 circulation models) conditions across the 40 NPAs.

609 Appendix 4. Number of species and records of each taxonomic group across the 61040 NPAs.

611

\section{ACKNOWLEDGEMENTS}

613 We thank Benjamin Blonder for his comments and contribution to improve this

614 manuscript. We thank the reviewers for their insightful and constructive comments

615 that substantially improved the manuscript.

616

\section{DECLARATION OF INTERESTS}

618 The authors declare that they have no conflict of interest to disclose. 


\section{REFERENCES}

621 Allen, C.D., Macalady, A.K., Chenchouni, H., Bachelet, D., McDowell, N., Vennetier, M.,

622

623

624

625

626

627

628

629

630

631

632

633

634

635

636

637

638

639

640

641

642

643

644

645

646

647

648

649

650

651

652

653

654

655

656

657

658

659

660

661

662

663

664

665

666

667 Kitzberger, T., Rigling, A., Breshears, D.D., Hogg, E.T., 2010. A global overview of drought and heat-induced tree mortality reveals emerging climate change risks for forests. Forest Ecology and Management 259, 660-684.

Anderegg, W.R., Flint, A., Huang, C.-y., Flint, L., Berry, J.A., Davis, F.W., Sperry, J.S., Field, C.B., 2015. Tree mortality predicted from drought-induced vascular damage. Nature Geoscience 8, 367-371.

Arriaga, L., Espinoza, J., Aguilar, C., Martínez, E., Gómez, L., Loa, E., 2000. Regiones terrestres prioritarias de México. Comisión Nacional para el Conocimiento y uso de la Biodiversidad (CONABIO), Mexico.

Batisse, M., 1982. The biosphere reserve: a tool for environmental conservation and management. Environmental Conservation 9, 101-111.

Baumgartner, J., Esperón-Rodríguez, M., Beaumont, L., 2018. Identifying in situ climate refugia for plants species. Ecography 41, 1-14.

Beaumont, L.J., Duursma, D., 2012. Global projections of 21st century land-use changes in regions adjacent to protected areas. PloS one 7, e43714.

Beaumont, L.J., Esperón-Rodríguez, M., Nipperess, D.A., Wauchope-Drumm, M., Baumgartner, J.B., 2019. Incorporating future climate uncertainty into the identification of climate change refugia for threatened species. Biological Conservation 237, 230-7.

Bennie, J., Hodgson, J.A., Lawson, C.R., Holloway, C.T., Roy, D.B., Brereton, T., Thomas, C.D. and Wilson, R.J., 2013. Range expansion through fragmented landscapes under a variable climate. Ecology Letters 16(7), 921-929.

Bezaury-Creel, J., Torres, J., Ochoa-Ochoa, L., Castro-Campos, M., Moreno, N., 2009. Base de Datos Geográfica de Áreas Naturales Protegidas Estatales y del Distrito Federal de México, 2009. Catálogo de metadatos geográficos. Comisión Nacional para el Conocimiento y Uso de la Biodiversidad (CONABIO), Mexico, DF.

Blonder, B., Lamanna, C., Violle, C., Enquist, B.J., 2014. The n-dimensional hypervolume. Global Ecology and Biogeography 23, 595-609.

Blonder, B., Harris, D., 2018. Hypervolume. High Dimensional Geometry and Set Operations Using Kernel Density Estimation, Support Vector Machines, and Convex Hulls.

Bonebrake, T.C., Brown, C.J., Bell, J.D., Blanchard, J.L., Chauvenet, A., Champion, C., Chen, I.C., Clark, T.D., Colwell, R.K., Danielsen, F., 2018. Managing consequences of climate-driven species redistribution requires integration of ecology, conservation and social science. Biological Reviews 93, 284-305.

Brenner, L., 2010. Gobernanza ambiental, actores sociales y conflictos en las Áreas Naturales Protegidas mexicanas. Revista Mexicana de Sociología 72, 283-310.

Brown, J.H., Kodric-Brown, A., 1977. Turnover rates in insular biogeography: effect of immigration on extinction. Ecology 58, 445- 449.

Brown, C.J., Bode, M., Venter, O., Barnes, M.D., McGowan, J., Runge, C.A., Watson, J.E. and Possingham, H.P., 2015. Effective conservation requires clear objectives and prioritizing actions, not places or species. Proceedings of the National Academy of Sciences 112(32), E4342-E4342.

Cao, L., Bala, G., Caldeira, K., Nemani, R. and Ban-Weiss, G., 2010. Importance of carbon dioxide physiological forcing to future climate change. Proceedings of the National Academy of Sciences 107(21), 9513-9518. 
668

669

670

671

672

673

674

675

676

677

678

679

680

681

682

683

684

685

686

687

688

689

690

691

692

693

694

695

696

697

698

699

700

701

702

703

704

705

706

707

708

709

710

711

712

713

714

715

716

Cash, D.W., Moser, S.C., 2000. Linking global and local scales: designing dynamic assessment and management processes. Global Environmental Change 10, 109120.

Cavazos, T., Salinas, J., Martínez, B., Colorado, G., De Grau, P., Prieto González, R., Bravo, M., 2013. Actualización de escenarios de cambio climático para México como parte de los productos de la Quinta Comunicación Nacional. Informe final del proyecto al INECC, Mexico, pp. 150.

Challenger, A., 1998. Utilización y conservación de los ecosistemas terrestres de México: pasado presente y futuro. CONABIO. IBUNAM. ASM, SC México.

$\mathrm{Cl}, 2002$. Evaluaciones de las afectaciones e impactos causados por las invasiones y ocupaciones irregulares a las áreas naturales protegidas de la Selva Lacandona de Chiapas (1994 - 2002). Reporte Interno p. 56. Sistema de Monitoreo Ambiental Programa Selva Maya, Tuxtla Gtz. Chiapas.

CONABIO, 1995. Reservas de la biosfera y otras áreas naturales protegidas de México, Mexico.

CONANP, 2006. Las áreas protegidas de México. Liderazgo Internacional. Comisión Nacional de Áreas Naturales Protegidas, México, DF.

Correa-Metrio, A., Meave, J.A., Lozano-García, S., Bush, M.B., 2014. Environmental determinism and neutrality in vegetation at millennial time scales. Journal of Vegetation Science 25, 627-635.

DeFries, R., Karanth, K.K., Pareeth, S., 2010. Interactions between protected areas and their surroundings in human-dominated tropical landscapes. Biological Conservation 143, 2870-2880.

Ervin, J., 2003. Protected area assessments in perspective. AIBS Bulletin 53, 819-822. Esperón-Rodríguez, M., Barradas, V.L., 2015a. Comparing environmental vulnerability in the montane cloud forest of eastern Mexico: A vulnerability index. Ecological Indicators 52, 300-310.

Esperón-Rodríguez, M., Barradas, V.L., 2015b. Ecophysiological vulnerability to climate change: water stress responses in four tree species from the central mountain region of Veracruz, Mexico. Regional Environmental Change 15, 93-108.

Farjon, A., 2013. Pinus cembroides ssp. lagunae. The IUCN Red List of Threatened Species 2013: e.T34185A2849785, http://dx.doi.org/10.2305/IUCN.UK.20131.RLTS.T34185A2849785.en. .

Fatichi, S., Ivanov, V.Y., Paschalis, A., Peleg, N., Molnar, P., Rimkus, S., Kim, J., Burlando, P., Caporali, E., 2016. Uncertainty partition challenges the predictability of vital details of climate change. Earth's Future 4, 240-251.

Fernández Eguiarte, A., Zavala Hidalgo, J., Romero Centeno, R., Conde Álvarez, A., Trejo Vázquez, R., 2015. Actualización de los escenarios de cambio climático para estudios de impactos, vulnerabilidad y adaptación. Centro de Ciencias de la Atmósfera, Universidad Nacional Autónoma de México. Instituto Nacional de Ecología y Cambio Climático, Secretaría de Medio Ambiente y Recursos Naturales.

Field, C., Barros, V., Dokken, D., Mach, K., Mastrandrea, M., Bilir, T., Chatterjee, M., Ebi, K., Estrada, Y., Genova, R., Girma, B., Kissel, E.S., Levy, A.N., MacCracken, S., Mastrandrea, P.R., White, L.L., 2014. IPCC, 2014: Climate Change 2014: Impacts, Adaptation, and Vulnerability. Part A: Global and Sectoral Aspects. Contribution of Working Group II to the Fifth Assessment Report of the Intergovernmental Panel on Climate Change. Cambridge University Press, Cambridge, United Kingdom and New York, NY, USA. 
Figueroa, F., Sánchez-Cordero, V., 2008. Effectiveness of natural protected areas to prevent land use and land cover change in Mexico. Biodiversity and Conservation $17,3223$.

Gallo-Reynoso, J., 1994. Factors affecting the population status of Guadalupe fur seal. PhD. Dissertation. University of California, Santa Cruz. pp. 199.

Graham, V., Baumgartner, J.B., Beaumont, L.J., Esperón-Rodríguez, M., Grech, A., 2019. Prioritizing the protection of climate refugia: designing a climate-ready protected area network. Journal of Environmental Planning and Management, 1-19.

Grierson, C.S., Barnes, S.R., Chase, M.W., Clarke, M., Grierson, D., Edwards, K.J., Jellis, G.J., Jones, J.D., Knapp, S., Oldroyd, G., Poppy, G., 2011. One hundred important questions facing plant science research. New Phytologist 192, 6-12.

Guevara, S., Laborde, J., Sánches-Ríos, G., 2004. La deforestación, In Los Tuxtlas. El paisaje de la sierra. eds S. Guevara, J. Laborde, G. Sánches-Ríos, pp. 85-108. Instituto de Ecología, A.C. and European Union, Xalapa, Mexico.

Guisan, A., Petitpierre, B., Broennimann, O., Daehler, C., Kueffer, C., 2014. Unifying niche shift studies: insights from biological invasions. Trends in Ecology \& Evolution 29, 260-269.

Hannah, L., 2008. Protected areas and climate change. Annals of the New York Academy of Sciences 1134, 201-212.

Hannah, L., Flint, L., Syphard, A.D., Moritz, M.A., Buckley, L.B., McCullough, I.M., 2014. Fine-grain modeling of species' response to climate change: holdouts, steppingstones, and microrefugia. Trends in Ecology \& Evolution 29, 390-397.

Hardy, O.J., Sonké, B., 2004. Spatial pattern analysis of tree species distribution in a tropical rain forest of Cameroon: assessing the role of limited dispersal and niche differentiation. Forest Ecology and Management 197(1-3), 191-202.

Harrison, S., Noss, R., 2017. Endemism hotspots are linked to stable climatic refugia. Annals of Botany 119, 207-214.

Henein, K., Merriam, G., 1990. The elements of connectivity where corridor quality is variable. Landscape Ecology 4(2-3), 157-170.

Hoegh-Guldberg, O., Hughes, L., McIntyre, S., Lindenmayer, D., Parmesan, C., Possingham, H.P., Thomas, C., 2008. Assisted colonization and rapid climate change. American Association for the Advancement of Science.

Hutchinson, G., 1957. A Treatise on limnology. Wiley-Interscience, New York.

Ishwaran, N., Persic, A., Tri, N.H., 2008. Concept and practice: the case of UNESCO biosphere reserves. International Journal of Environment and Sustainable Development 7, 118-131.

IUCN, 2005. The World Conservation Union. Benefits Beyond Boundaries: Proceedings of the Vth IUCN World Parks Congress: Durban, South Africa 8-17 September 2003. IUCN.

Keppel, G., Van Niel, K.P., Wardell-Johnson, G.W., Yates, C.J., Byrne, M., Mucina, L., Schut, A.G., Hopper, S.D., Franklin, S.E., 2012. Refugia: identifying and understanding safe havens for biodiversity under climate change. Global Ecology and Biogeography 21, 393-404.

Keppel, G., Wardell-Johnson, G.W., 2015. Refugial capacity defines holdouts, microrefugia and stepping-stones: a response to Hannah et al. Trends in Ecology \& Evolution 30, 233-234.

Knapp, A.K., Beier, C., Briske, D.D., Classen, A.T., Luo, Y., Reichstein, M., Smith, M.D., Smith, S.D., Bell, J.E., Fay, P.A., 2008. Consequences of more extreme precipitation regimes for terrestrial ecosystems. AIBS Bulletin 58, 811-821.

Legendre, P., Legendre, L.F., 2012. Numerical ecology, Third edition edn. Elsevier, Oxford, UK. 
768

769

770

771

772

773

774

775

776

777

778

779

780

781

782

783

784

785

786

787

788

789

790

791

792

793

794

795

796

797

798

799

800

801

802

803

804

805

806

807

808

809

810

811

812

813

814

815

816

Lemoine, N.P., 2015. Climate change may alter breeding ground distributions of eastern migratory monarchs (Danaus plexippus) via range expansion of Asclepias host plants. PloS one 10, e0118614.

Lenoir, J., Gégout, J.-C., Marquet, P., De Ruffray, P., Brisse, H., 2008. A significant upward shift in plant species optimum elevation during the 20th century. Science $320,1768-1771$.

Lenoir, J., Svenning, J.C., 2015. Climate-related range shifts-a global multidimensional synthesis and new research directions. Ecography 38, 15-28.

Lenoir, J., Hattab, T., Pierre, G., 2017. Climatic microrefugia under anthropogenic climate change: implications for species redistribution. Ecography 40(2), 253-266.

Loarie, S., Duffy, P., Hamilton, H., Asner, G., Field, C., Ackerly, D., 2009. The velocity of climate change. Nature 462, 1052-1055.

Mawdsley, J.R., O'malley, R., Ojima, D.S., 2009. A review of climate-change adaptation strategies for wildlife management and biodiversity conservation. Conservation Biology 23, 1080-1089.

McCain, C.M., Colwell, R.K., 2011. Assessing the threat to montane biodiversity from discordant shifts in temperature and precipitation in a changing climate. Ecology Letters 14, 1236-1245.

McCune, B., Grace, J., Urban, D., 2002. Analysis of ecological communities. MjM Software Design, Gleneden Beach, Oregon, USA. ISBN 0-9721290-0-6.

McDonald-Madden, E., Runge, M.C., Possingham, H.P. and Martin, T.G., 2011. Optimal timing for managed relocation of species faced with climate change. Nature Climate Change 1(5), 261-265.

Médail, F., Diadema, K., 2009. Glacial refugia influence plant diversity patterns in the Mediterranean Basin. Journal of Biogeography 36, 1333-1345.

Meinshausen, M., Smith, S.J., Calvin, K., Daniel, J.S., Kainuma, M., Lamarque, J., Matsumoto, K., Montzka, S., Raper, S., Riahi, K., 2011. The RCP greenhouse gas concentrations and their extensions from 1765 to 2300. Climatic Change 109, 213241.

Mimura, N., 1999. Vulnerability of island countries in the South Pacific to sea level rise and climate change. Climate Research 12, 137-143.

Mimura, N., Nurse, L., McLean, R., Agard, J., Briguglio, L., Lefale, P., Payet, R., Sem, G., 2007. Small islands. Climate Change 16, 687-716.

Mittermeier, R.A., Myers, N., Thomsen, J.B., Da Fonseca, G.A., Olivieri, S., 1998. Biodiversity hotspots and major tropical wilderness areas: approaches to setting conservation priorities. Conservation Biology 12, 516-520.

Moles, A.T., Perkins, S.E., Laffan, S.W., Flores-Moreno, H., Awasthy, M., Tindall, M.L., Sack, L., Pitman, A., Kattge, J., Aarssen, L.W., 2014. Which is a better predictor of plant traits: temperature or precipitation? Journal of Vegetation Science 25, 11671180.

Nicholls, R.J., Cazenave, A., 2010. Sea-level rise and its impact on coastal zones. Science 328, 1517-1520.

Nogués-Bravo, D., Araújo, M.B., Errea, M., Martinez-Rica, J., 2007. Exposure of global mountain systems to climate warming during the 21 st Century. Global Environmental Change 17, 420-428.

O'Donnell, M.S., Ignizio, D.A., 2012. Bioclimatic predictors for supporting ecological applications in the conterminous United States. US Geological Survey Data Series 691.

Ohlemüller, R., 2011. Running out of climate space. Science 334, 613-614. 
Oksanen, G., Blanchet, F., Friendly, M., Kindt, R., Legendre, P., McGlinn, D., Minchin, P., O'Hara, R., Simpson, G., Solymos, P., Stevens, H., Szoecs, E., Wagner, H., 2019. Vegan, ed. C.E. Package.

Pacheco, J., Ceballos, G., List, R., 2000. Los mamíferos de la región de Janos-Casas Grandes, Chihuahua, México. Revista Mexicana de Mastozoología 4, 71-85.

Pearson, R.G., 2006. Climate change and the migration capacity of species. Trends in Ecology \& Evolution 21, 111-113.

Pecl, G.T., Araújo, M.B., Bell, J.D., Blanchard, J., Bonebrake, T.C., Chen, I.-C., Clark, T.D., Colwell, R.K., Danielsen, F., Evengård, B., 2017. Biodiversity redistribution under climate change: Impacts on ecosystems and human well-being. Science 355, eaai9214.

Pellegrini, A.F., Anderegg, W.R., Paine, C., Hoffmann, W.A., Kartzinel, T., Rabin, S.S., Sheil, D., Franco, A.C., Pacala, S.W., 2017. Convergence of bark investment according to fire and climate structures ecosystem vulnerability to future change. Ecology Letters 20, 307-316.

$\mathrm{R}$ Core Team, 2018. R: A language and environment for statistical computing. $\mathrm{R}$ Foundation for Statistical Computing, Vienna, Austria.

Raftery, A.E., Zimmer, A., Frierson, D.M., Startz, R. and Liu, P., 2017. Less than $2^{\circ} \mathrm{C}$ warming by 2100 unlikely. Nature Climate Change 7(9), 637-641.

Riahi, K., Rao, S., Krey, V., Cho, C., Chirkov, V., Fischer, G., Kindermann, G., Nakicenovic, N., Rafaj, P., 2011. RCP 8.5-A scenario of comparatively high greenhouse gas emissions. Climatic Change 109(1-2), 33-57.

Sarukhán Kermez, J., Dirzo, R., 1992. México ante los retos de la biodiversidad. Comisión Nacional para el Conocimiento y Uso de la Biodiversidad, Mexico, DF.

Scheffers, B.R., De Meester, L., Bridge, T.C., Hoffmann, A.A., Pandolfi, J.M., Corlett, R.T., Butchart, S.H., Pearce-Kelly, P., Kovacs, K.M., Dudgeon, D., 2016. The broad footprint of climate change from genes to biomes to people. Science 354, aaf7671.

SEDATU, 2017. Atlas de Peligros y/o Riesgos del municipio de Tapachula, Chiapas 2017, p. 239. Secretaría de Desarrollo Agrario, Territorial y Urban, Mexico.

SEMARNAT, 2015. Inventarios forestales y tasas de deforestación. Secretaría de Medio Ambiente y Recursos Naturales, Mexico.

SEMARNAT, 2017. Programa para la conservación, recuperación, reproducción y repoblación de la vaquita marina (phocoena sinus) en su hábitat, p. 73. Secretaría de Medio Ambiente y Recursos Naturales, Mexico.

Smith, R.J., Bennun, L., Brooks, T.M., Butchart, S.H., Cuttelod, A., Di Marco, M., Ferrier, S., Fishpool, L.D., Joppa, L., Juffe-Bignoli, D. and Knight, A.T., 2019. Synergies between the key biodiversity area and systematic conservation planning approaches. Conservation Letters 12(1), e12625

Temme, A.A., Liu, J.C., Cornwell, W.K., Aerts, R., Cornelissen, J.H., 2019. Hungry and thirsty: Effects of $\mathrm{CO}_{2}$ and limited water availability on plant performance. Flora 254, 188-193.

Thomas, C.D., Cameron, A., Green, R.E., Bakkenes, M., Beaumont, L.J., Collingham, Y.C., Erasmus, B.F.N., de Siqueira, M.F., Grainger, A., Hannah, L., Hughes, L., Huntley, B., van Jaarsveld, A.S., Midgley, G.F., Miles, L., Ortega-Huerta, M.A., Townsend Peterson, A., Phillips, O.L., Williams, S.E., 2004. Extinction risk from climate change. Nature 427, 145-148.

Tzedakis, P., Lawson, I., Frogley, M., Hewitt, G., Preece, R., 2002. Buffered tree population changes in a Quaternary refugium: evolutionary implications. Science 297, 2044-2047. 
UNESCO, 2017. A New Roadmap for the Man and the Biosphere (MAB) Programme and its World Network of Biosphere Reserves. United Nations Educational, Scientific and Cultural Organization, Paris, France.

Vargas Márquez, F., de la Maza-Elvira, R., del Pont-Lalli, R., 2011. Áreas naturales protegidas de México con decretos estatales. Instituto Nacional de Ecología y Comisión Nacional de Áreas Naturales Protegidas, Mexico, DF, pp. 620.

Villalobos, I., 2000. Áreas naturales protegidas: instrumento estratégico para la conservación de la biodiversidad. Gaceta Ecológica, 24-34.

Walther, G.-R., Post, E., Convey, P., Menzel, A., Parmesan, C., Beebee, T.J., Fromentin, J.-M., Hoegh-Guldberg, O., Bairlein, F., 2002. Ecological responses to recent climate change. Nature 416, 389-395.

Weltzin, J.F., Loik, M.E., Schwinning, S., Williams, D.G., Fay, P.A., Haddad, B.M., Harte, J., Huxman, T.E., Knapp, A.K., Lin, G., 2003. Assessing the response of terrestrial ecosystems to potential changes in precipitation. BioScience 53, 941-952.

Yu, M., Wang, G., Parr, D., Ahmed, K.F., 2014. Future changes of the terrestrial ecosystem based on a dynamic vegetation model driven with RCP8. 5 climate projections from $19 \mathrm{GCMs}$. Climatic Change 127(2), 257-271.

Zhu, Z., Piao, S., Myneni, R.B., Huang, M., Zeng, Z., Canadell, J.G., Ciais, P., Sitch, S., Friedlingstein, P., Arneth, A., Cao, C., 2016. Greening of the Earth and its drivers. Nature climate change 6(8), 791-795 


\section{SUPPLEMENTARY MATERIAL}

Changes in climatic space threaten the most biodiverse regions of Mexico

\section{Appendix 1}

Pearson correlation of 19 bioclimatic variables

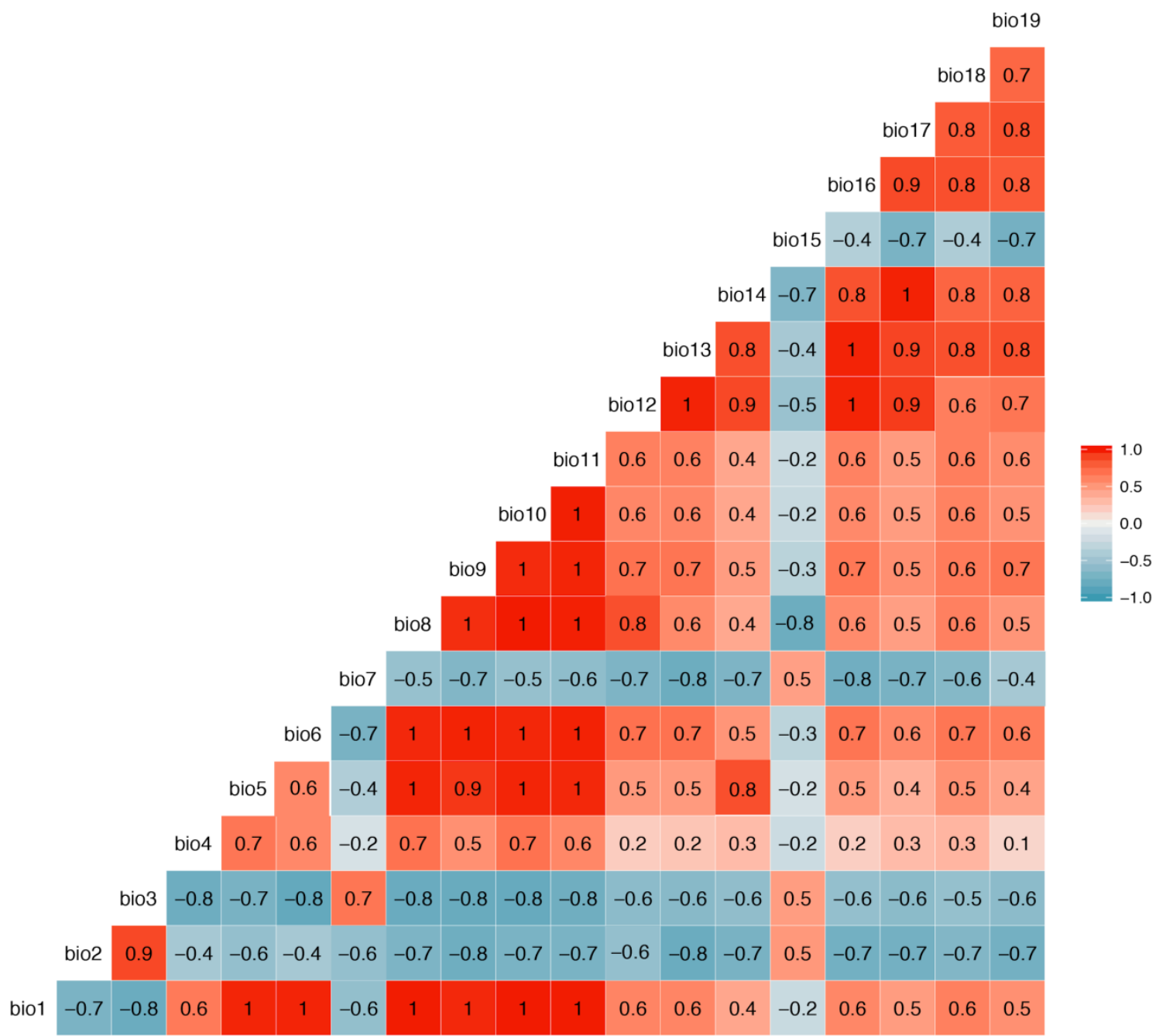

Figure A1. Pearson correlation of 19 bioclimatic variables (data from WorldClim

(http://www.worldclim.org/). Bioclimatic variables are coded as follows:

$\mathrm{BIO1}=$ Annual Mean Temperature

$\mathrm{BIO} 2=$ Mean Diurnal Range $($ Mean of monthly $(\max$ temp - min temp $))$ 
$\mathrm{BIO} 3=$ Isothermality $(\mathrm{BIO} 2 / \mathrm{BIO} 7)\left({ }^{*} 100\right)$

$\mathrm{BIO} 4=$ Temperature Seasonality (standard deviation *100)

$\mathrm{BIO5}=$ Max Temperature of Warmest Month

BIO6 = Min Temperature of Coldest Month

$\mathrm{BIO} 7=$ Temperature Annual Range $(\mathrm{BIO5}-\mathrm{BIO})$

$\mathrm{BIO8}=$ Mean Temperature of Wettest Quarter

$\mathrm{BIO9}=$ Mean Temperature of Driest Quarter

$\mathrm{BIO10}=$ Mean Temperature of Warmest Quarter

BIO11 = Mean Temperature of Coldest Quarter

$\mathrm{BIO12}=$ Annual Precipitation

BIO13 $=$ Precipitation of Wettest Month

BIO14 = Precipitation of Driest Month

BIO15 $=$ Precipitation Seasonality (Coefficient of Variation)

BIO16 $=$ Precipitation of Wettest Quarter

BIO17 = Precipitation of Driest Quarter

BIO18 = Precipitation of Warmest Quarter

BIO19 $=$ Precipitation of Coldest Quarter 


\section{Appendix 2}

Changes in climate were assessed comparing baseline (averages between 1960 and 1990) and future (2050 [average for 2041-2060]; average of four global circulation models) conditions of five bioclimatic variables :1) Max Temperature of Warmest Month (MTWM); 2) Min Temperature of Coldest Month (MTCM); 3) Temperature Annual Range (TAN); 4) Annual Precipitation (AP); and 5) Precipitation Seasonality (PS) of 40 natural protected areas of Mexico.

Table A2.1. Mean, standard deviation [SD], minimum (Min) and maximum (Max) values across 40 protected areas of Mexico, for baseline (1960-1990) and future (2050 [average for 2041-2060]; average of four global circulation models) conditions. The bioclimatic variables are: (1) Max Temperature of Warmest Month $\left(M T W M ;{ }^{\circ} \mathrm{C}\right) ;(2)$ Min Temperature of Coldest Month (MTCM; $\left.{ }^{\circ} \mathrm{C}\right) ;(3)$ Temperature Annual Range ( $\left.T A N ;{ }^{\circ} \mathrm{C}\right)$; (4) Annual Precipitation (AP; mm); and (5) Precipitation Seasonality (PS; \%). Protected areas in brackets indicate where min and max values were found. Mean and SD were obtained from of all grid cells across protected areas.

\begin{tabular}{|c|c|c|c|c|}
\hline Variable & Time period & Mean [SD] & Min & Max \\
\hline \multirow[t]{6}{*}{ MTWM } & Baseline & $33.7[4.1]$ & 24 & 40.6 \\
\hline & & & (Mariposa & (Alto Golfo de \\
\hline & & & Monarca) & California) \\
\hline & Future & $35.1[3.8]$ & 27.2 & 43.7 \\
\hline & & & (Isla Guadalupe) & (Alto golfo de \\
\hline & & & & California) \\
\hline
\end{tabular}




\begin{tabular}{|c|c|c|c|c|}
\hline \multirow[t]{4}{*}{ MTCM } & \multirow[t]{2}{*}{ Baseline } & \multirow[t]{2}{*}{$12.4[5.6]$} & \multirow{2}{*}{$\begin{array}{c}-0.5 \\
\text { (Janos) }\end{array}$} & \multirow{2}{*}{$\begin{array}{c}19.1 \\
\text { (La Encrucijada) }\end{array}$} \\
\hline & & & & \\
\hline & Future & $13.4[5.6]$ & 2 & 21.3 \\
\hline & & & (Janos) & (La Encrucijada) \\
\hline \multirow[t]{4}{*}{ TAN } & Baseline & $21.3[5.9]$ & 13.2 & 38.3 \\
\hline & & & (Isla Guadalupe) & (Janos) \\
\hline & Future & $21.6[5.8]$ & 13.5 & 39.6 \\
\hline & & & (Isla Guadalupe) & (Janos) \\
\hline \multirow[t]{6}{*}{$A P$} & Baseline & $968[748.4]$ & 77 & 3720 \\
\hline & & & (Alto Golfo de & (Montes Azules) \\
\hline & & & California) & \\
\hline & Future & $948.8[749.2]$ & 75.75 & 3543 \\
\hline & & & (Alto Golfo de & (Montes Azules) \\
\hline & & & California) & \\
\hline \multirow[t]{4}{*}{$P S$} & Baseline & 83 [19.7] & 47 & 131 \\
\hline & & & (Tiburón Ballena) & (Sierra de la Laguna) \\
\hline & Future & $84.1[19.9]$ & 53.8 & 139.3 \\
\hline & & & (Tiburón Ballena) & (Sierra de la Laguna) \\
\hline
\end{tabular}



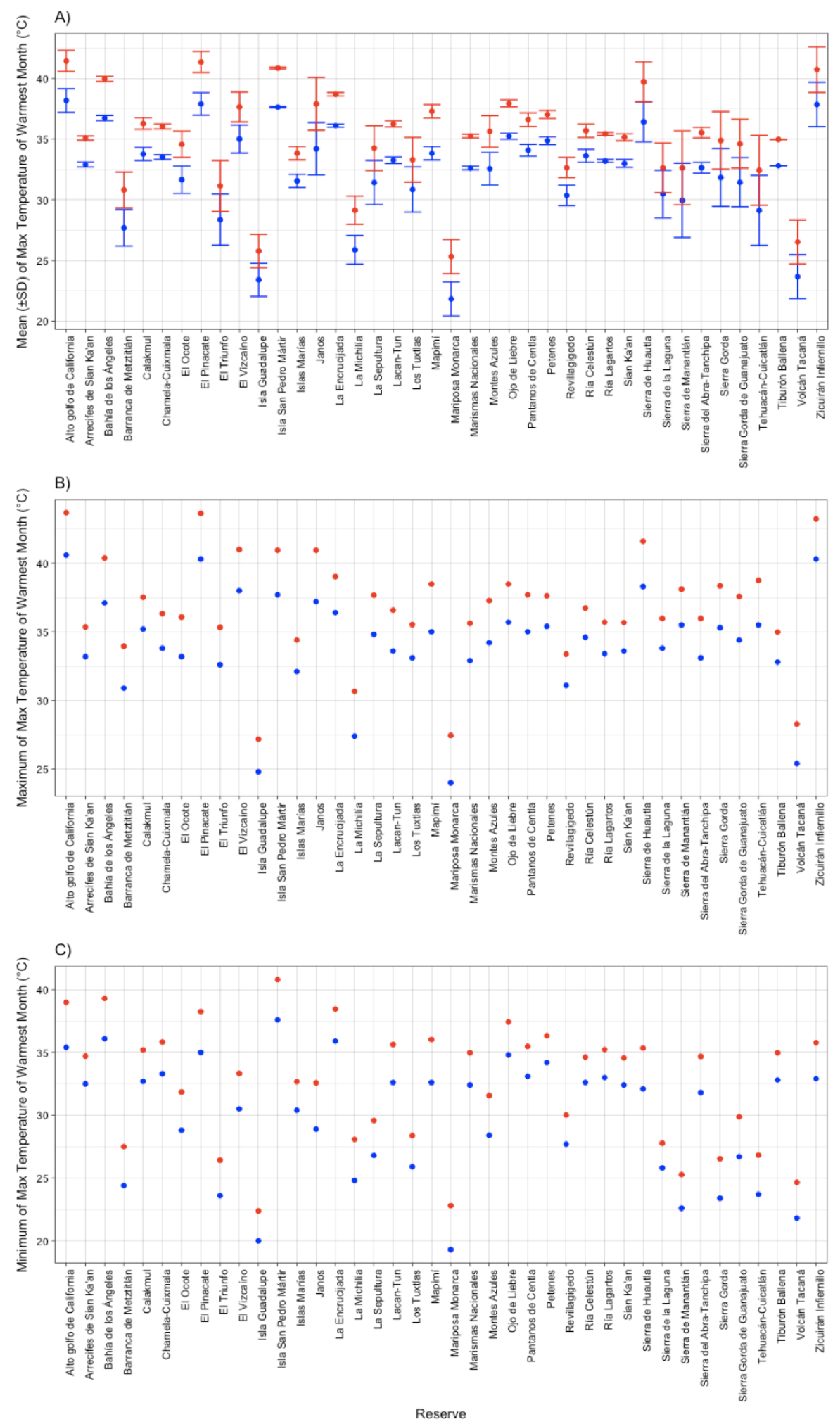

Figure A2.1. Changes in mean and standard deviation (A), maximum (B) and minimum (C) values of Max Temperature of Warmest Month (MTWM) comparing two time periods (blue: baseline, 1960-1990; red: future, 2050 [average for 20412060]) for 40 protected areas of Mexico. 

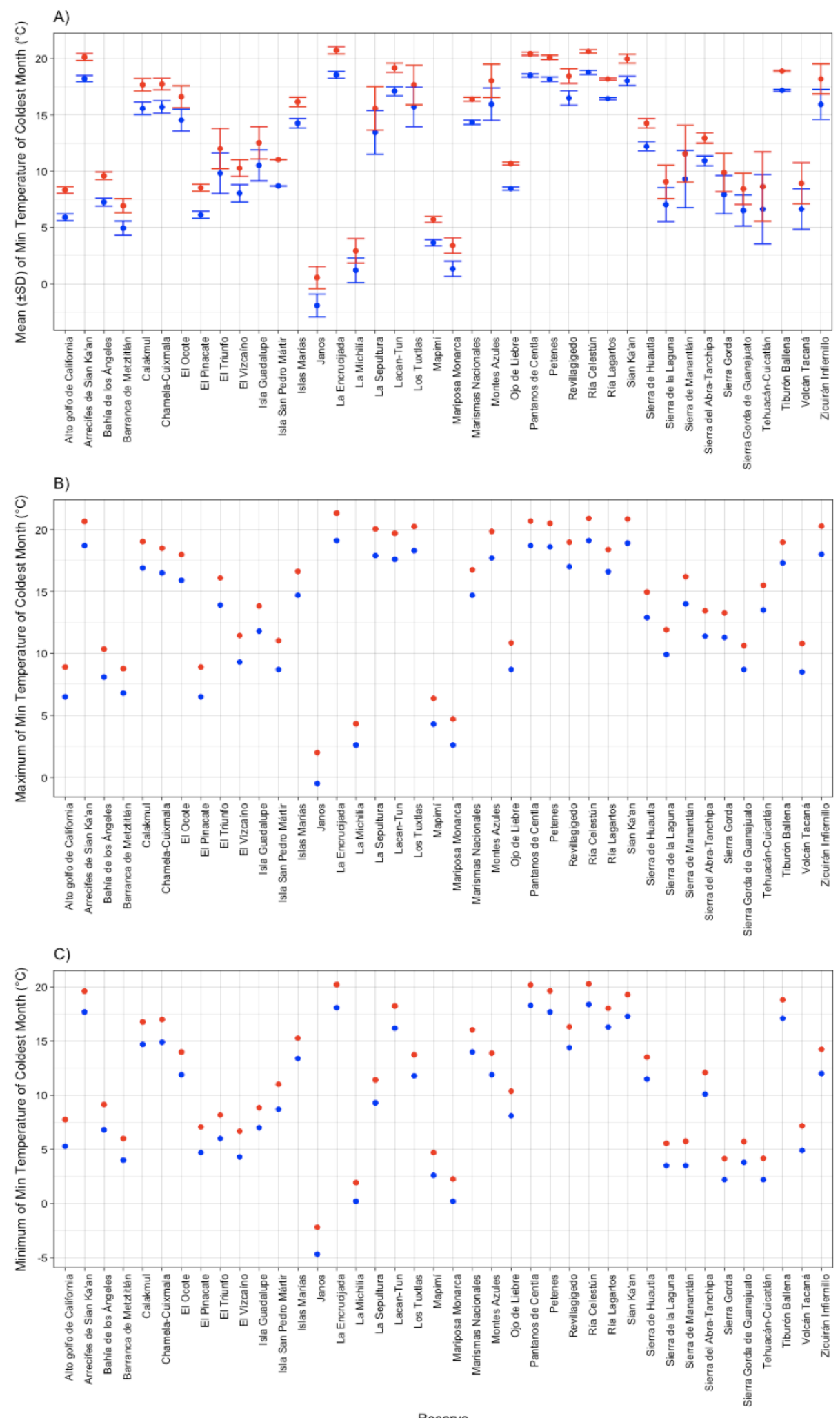

Figure A2.2. Changes in mean and standard deviation (A), maximum (B) and minimum (C) values of Min Temperature of Coldest Month (MTCM) comparing two time periods (blue: baseline, 1960-1990; red: future, 2050 [average for 2041-2060]) for 40 protected areas of Mexico. 

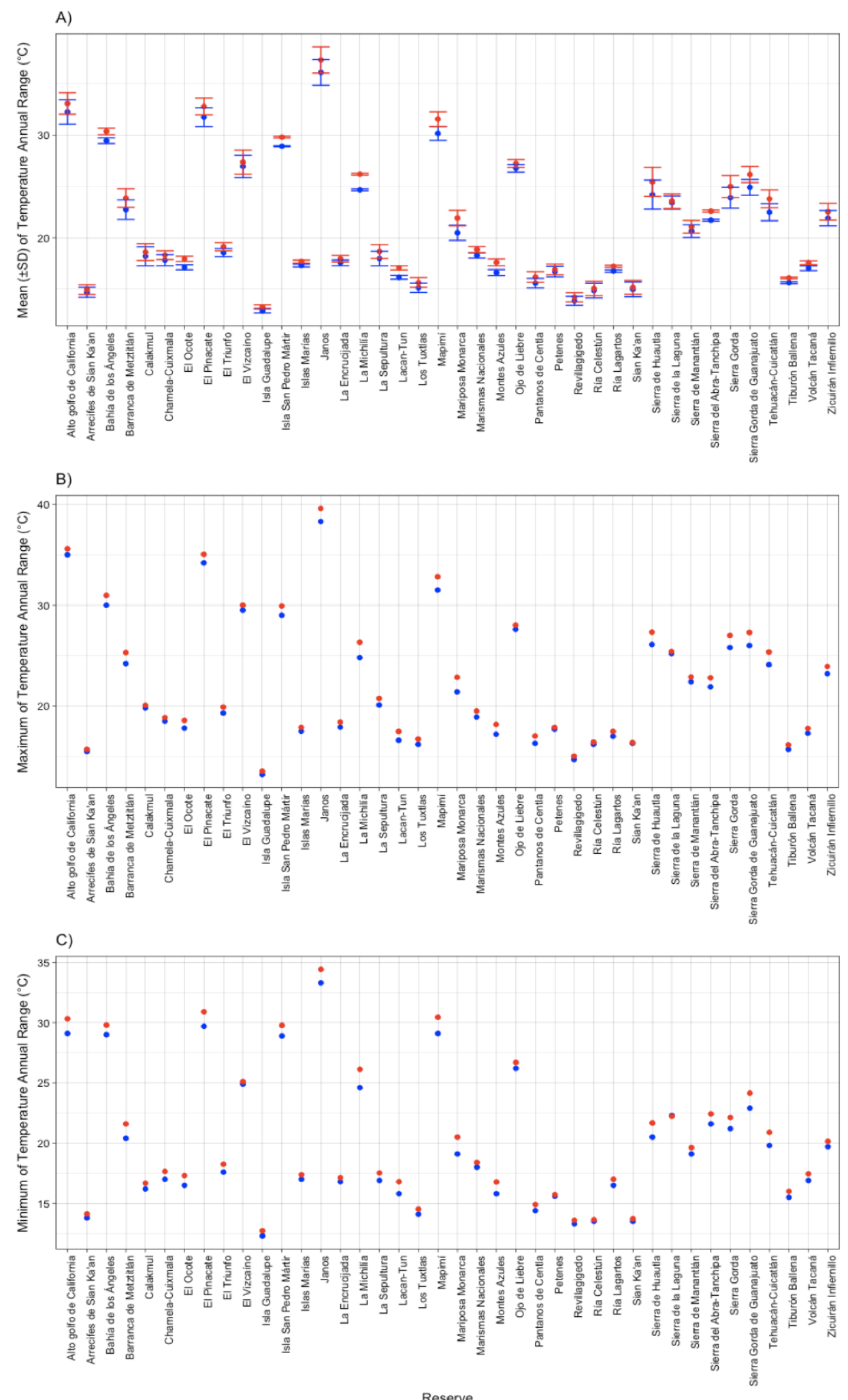

Figure A2.3. Changes in mean and standard deviation (A), maximum (B) and minimum (C) values of Temperature Annual Range (TAN) comparing two time periods (blue: baseline, 1960-1990; red: future, 2050 [average for 2041-2060]) for 40 protected areas of Mexico. 

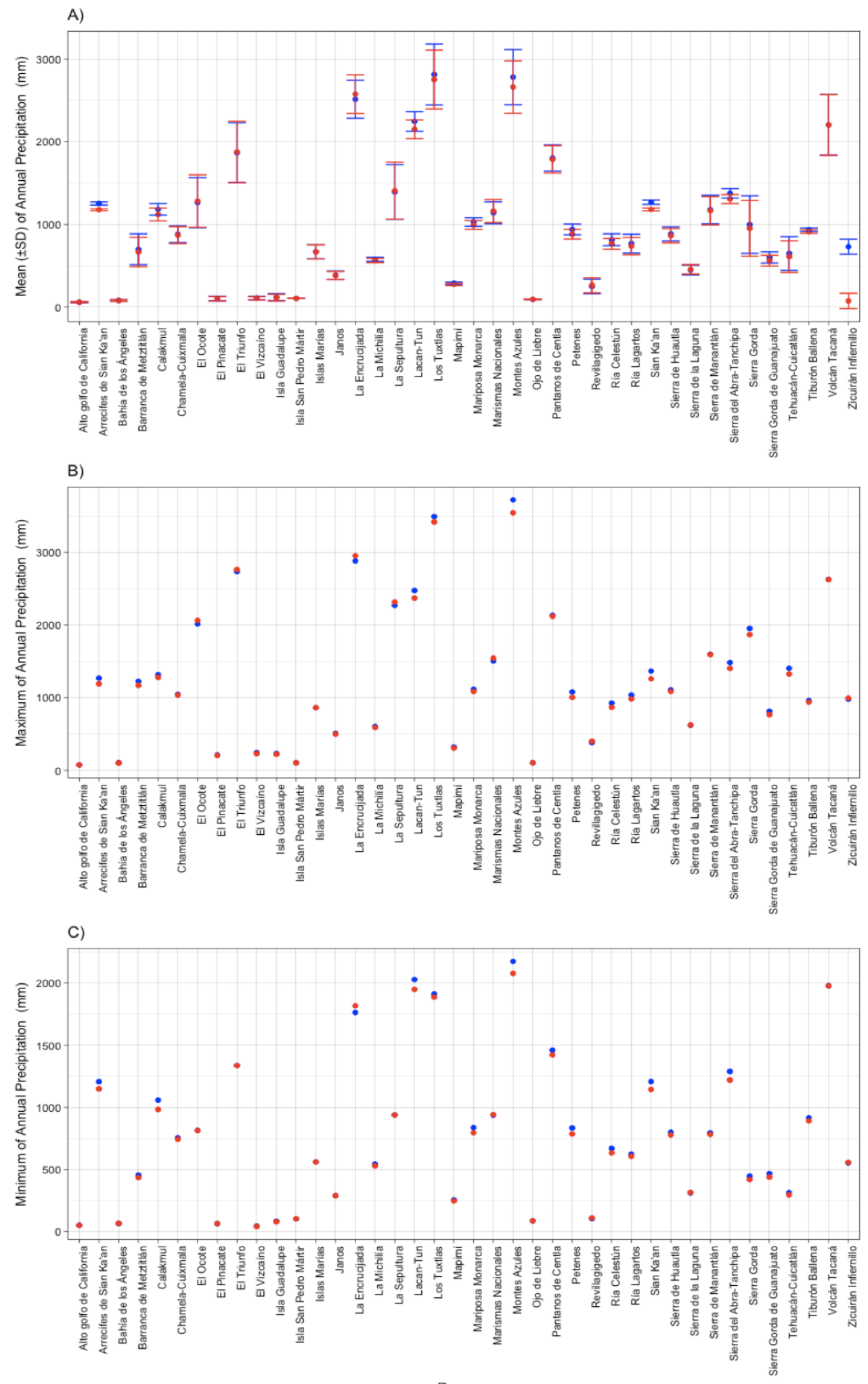

Figure A2.4. Changes in mean and standard deviation (A), maximum (B) and minimum (C) values of Annual Precipitation $(A P)$ comparing two time periods (blue: baseline, 1960-1990; red: future, 2050 [average for 2041-2060]) for 40 protected areas of Mexico. 

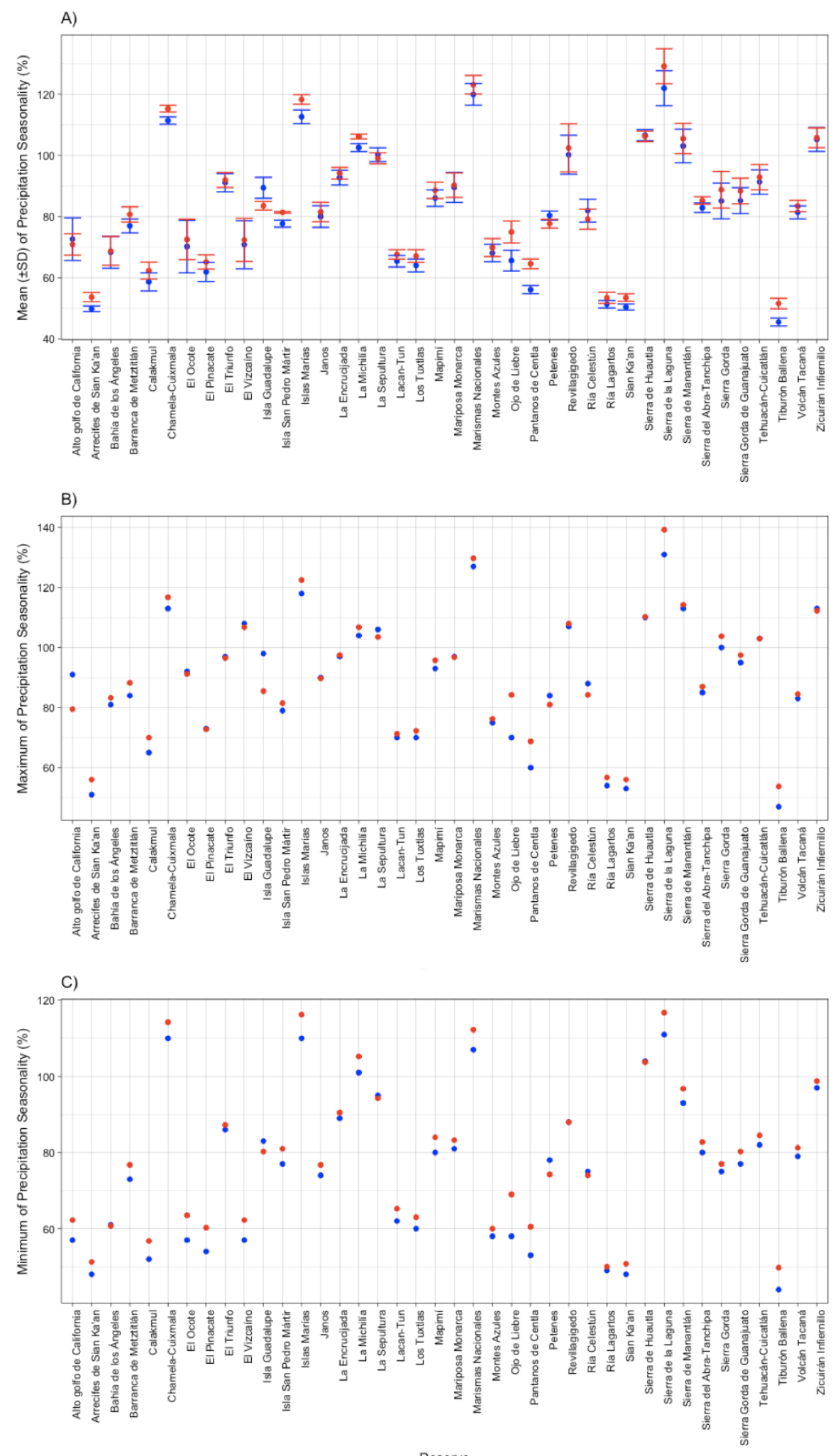

Figure A2.5. Changes in mean and standard deviation (A), maximum (B) and minimum $(C)$ values of Precipitation Seasonality $(P S)$ comparing two time periods (blue: baseline, 1960-1990; red: future, 2050 [average for 2041-2060]) for 40 protected areas of Mexico. 


\section{Appendix 3}

Changes in climate spaces comparing baseline (averages between 1960 and 1990 ) and future (2050 [average for 2041-2060]; average of four global circulation models) conditions across the 40 NPAs.

Table A3.1. For 40 protected areas of Mexico, we estimated baseline (BCS) and future (FCS) climatic space, the stable climatic space (i.e. intersection of baseline and future climatic spaces, as a proportion of the baseline hypervolume), the loss of climatic space (i.e. proportion of baseline climatic space that is no longer represented in the future) and the gain of novel climatic space (i.e. the proportion of future climatic space that was not represented under current climate). Additionally, we used the loss of analogue climate, total area and the number of species at each protected area to develop a comparative vulnerability index ( $V$ ) that allowed us to rank these protected areas according to their vulnerability from high (1) to low (40). The unit of BCS and FCS is the product of the units (SD) of the five environmental variables.

\begin{tabular}{|c|c|c|c|c|c|c|c|c|c|}
\hline $\begin{array}{c}\text { Protected } \\
\text { area }\end{array}$ & BCS & FCS & $\begin{array}{c}\text { Stable } \\
(\%)\end{array}$ & $\begin{array}{l}\text { Loss } \\
(\%)\end{array}$ & $\begin{array}{l}\text { Gain } \\
(\%)\end{array}$ & $\begin{array}{l}\text { Area } \\
\left(\mathbf{k m}^{2}\right)\end{array}$ & Species & $V$ & Rank \\
\hline $\begin{array}{l}\text { Alto G } \\
\text { olfo de }\end{array}$ & & & & & & & & & \\
\hline $\begin{array}{l}\text { California y } \\
\text { delta del rio } \\
\text { Colorado }\end{array}$ & 23.1 & 11.9 & 0 & 100 & 100 & 9347.6 & 941 & 0.58 & 36 \\
\hline
\end{tabular}




\begin{tabular}{|c|c|c|c|c|c|c|c|c|c|}
\hline $\begin{array}{c}\text { Protected } \\
\text { area }\end{array}$ & BCS & FCS & $\begin{array}{c}\text { Stable } \\
(\%)\end{array}$ & $\begin{array}{l}\text { Loss } \\
(\%)\end{array}$ & $\begin{array}{l}\text { Gain } \\
(\%)\end{array}$ & $\begin{array}{l}\text { Area } \\
\left(\mathrm{km}^{2}\right)\end{array}$ & Species & $V$ & Rank \\
\hline $\begin{array}{l}\text { Archipielago } \\
\text { de } \\
\text { Revillagiged } \\
\text { o }\end{array}$ & 59.7 & 96.6 & 0 & 100 & 100 & 6366.9 & 587 & 0.61 & 33 \\
\hline $\begin{array}{l}\text { Arrecifes de } \\
\text { Sian Ka'an }\end{array}$ & 181.3 & 32.4 & 0 & 100 & 100 & 349.3 & 864 & 0.70 & 21 \\
\hline $\begin{array}{l}\text { Bahia de los } \\
\text { Angeles, } \\
\text { canales de } \\
\text { Ballenas y } \\
\text { de } \\
\text { Salsipuedes }\end{array}$ & 108.2 & 80.4 & 0 & 100 & 100 & 3879.6 & 1256 & 0.67 & 28 \\
\hline $\begin{array}{l}\text { Barranca de } \\
\text { Metztitlan }\end{array}$ & 50.8 & 56.8 & 0 & 100 & 100 & 960.4 & 3223 & 0.80 & 5 \\
\hline Calakmul & 17.7 & 10.1 & 0 & 100 & 100 & 7231.9 & 3099 & 0.71 & 20 \\
\hline $\begin{array}{l}\text { Chamela- } \\
\text { Cuixmala }\end{array}$ & 182.3 & 54.1 & 0 & 100 & 100 & 131.4 & 1967 & 0.75 & 11 \\
\hline $\begin{array}{l}\text { Complejo } \\
\text { Lagunar Ojo } \\
\text { de Liebre }\end{array}$ & 98.4 & 65.6 & 0 & 100 & 100 & 603.4 & 654 & 0.69 & 23 \\
\hline $\begin{array}{l}\text { El Pinacate } \\
\text { y Gran } \\
\text { Desierto de } \\
\text { Altar }\end{array}$ & 41.3 & 26.5 & 0 & 100 & 100 & 7145.6 & 542 & 0.60 & 35 \\
\hline El Triunfo & 57.2 & 148.9 & 37.7 & 62.27 & $\begin{array}{r}57.9 \\
9\end{array}$ & 1191.8 & 4280 & 0.71 & 17 \\
\hline
\end{tabular}




\begin{tabular}{|c|c|c|c|c|c|c|c|c|c|}
\hline $\begin{array}{l}\text { Protected } \\
\text { area }\end{array}$ & BCS & FCS & $\begin{array}{c}\text { Stable } \\
(\%)\end{array}$ & $\begin{array}{l}\text { Loss } \\
\text { (\%) }\end{array}$ & $\begin{array}{l}\text { Gain } \\
(\%)\end{array}$ & $\begin{array}{l}\text { Area } \\
\left(\mathrm{km}^{2}\right)\end{array}$ & Species & $V$ & Rank \\
\hline El Vizcaino & 22.6 & 19.2 & 0 & 100 & 100 & $\begin{array}{r}24930 . \\
9\end{array}$ & 2619 & 0.45 & 38 \\
\hline $\begin{array}{l}\text { Isla } \\
\text { Guadalupe }\end{array}$ & 89.6 & 207.4 & 0 & 100 & 100 & 4769.7 & 461 & 0.62 & 32 \\
\hline $\begin{array}{l}\text { Isla San } \\
\text { Pedro Martir }\end{array}$ & 271.2 & 287.3 & 56.7 & 43.29 & $\begin{array}{r}42.8 \\
2\end{array}$ & 301.7 & 98 & 0.48 & 37 \\
\hline Islas Marias & 112.3 & 165.9 & 0 & 100 & 100 & 6412.9 & 559 & 0.61 & 34 \\
\hline Janos & 20.0 & 25.5 & 1.1 & 98.77 & $\begin{array}{r}99.0 \\
3\end{array}$ & 5264.8 & 1427 & 0.66 & 31 \\
\hline $\begin{array}{l}\text { La } \\
\text { Encrucijada }\end{array}$ & 41.1 & 19.9 & 0 & 100 & 100 & 1448.7 & 3196 & 0.79 & 6 \\
\hline La Michilia & 203.0 & 593.7 & 86.1 & 13.87 & 6.70 & 93.3 & 501 & 0.40 & 39 \\
\hline La Sepultura & 44.3 & 60.7 & 15 & 84.97 & $\begin{array}{r}83.7 \\
1\end{array}$ & 1673.1 & 4056 & 0.77 & 8 \\
\hline Lacan-Tun & 85.3 & 87.3 & 0 & 100 & 100 & 618.7 & 1344 & 0.72 & 15 \\
\hline Los Petenes & 74.8 & 31.6 & 0 & 100 & 100 & 2828.6 & 1098 & 0.68 & 26 \\
\hline Los Tuxtlas & 73.7 & 160.4 & 0 & 100 & 100 & 1551.2 & 5945 & 0.91 & 1 \\
\hline Mapimi & 49.0 & 31.7 & 0 & 100 & 100 & 3423.9 & 963 & 0.66 & 30 \\
\hline $\begin{array}{l}\text { Mariposa } \\
\text { Monarca }\end{array}$ & 67.9 & 107.2 & 0 & 100 & 100 & 562.6 & 2194 & 0.76 & 10 \\
\hline $\begin{array}{l}\text { Marismas } \\
\text { Nacionales }\end{array}$ & 47.2 & 24.6 & 0 & 100 & 100 & 1338.5 & 825 & 0.69 & 24 \\
\hline
\end{tabular}




\begin{tabular}{|c|c|c|c|c|c|c|c|c|c|}
\hline $\begin{array}{l}\text { Protected } \\
\text { area }\end{array}$ & BCS & FCS & $\begin{array}{c}\text { Stable } \\
(\%)\end{array}$ & $\begin{array}{l}\text { Loss } \\
(\%)\end{array}$ & $\begin{array}{l}\text { Gain } \\
(\%)\end{array}$ & $\begin{array}{l}\text { Area } \\
\left(\mathbf{k m}^{2}\right)\end{array}$ & Species & $v$ & Rank \\
\hline $\begin{array}{l}\text { Montes } \\
\text { Azules }\end{array}$ & 44.3 & 94.8 & 0 & 100 & 100 & 3312.0 & 4785 & 0.83 & 3 \\
\hline $\begin{array}{l}\text { Pantanos de } \\
\text { Centla }\end{array}$ & 36.6 & 59.9 & 0 & 100 & 100 & 3027.1 & 1424 & 0.69 & 22 \\
\hline $\begin{array}{l}\text { Reserva de } \\
\text { la biosfera } \\
\text { Zicuiran } \\
\text { Infiernillo }\end{array}$ & 36.1 & 46.5 & 0 & 100 & 100 & 2651.2 & 1781 & 0.71 & 18 \\
\hline Ria Celestun & 38.5 & 23.0 & 0 & 100 & 100 & 814.8 & 1166 & 0.71 & 19 \\
\hline Ria Lagartos & 79.4 & 82.7 & 0 & 100 & 100 & 603.5 & 1453 & 0.72 & 14 \\
\hline $\begin{array}{l}\text { Selva El } \\
\text { Ocote }\end{array}$ & 63.9 & 131.0 & 0 & 100 & 100 & 1012.9 & 3697 & 0.82 & 4 \\
\hline Sian Ka'an & 22.1 & 6.1 & 0 & 100 & 100 & 5281.5 & 2688 & 0.72 & 16 \\
\hline $\begin{array}{l}\text { Sierra de } \\
\text { Huautla }\end{array}$ & 91.9 & 74.8 & 0 & 100 & 100 & 590.3 & 2308 & 0.76 & 9 \\
\hline $\begin{array}{l}\text { Sierra de la } \\
\text { Laguna }\end{array}$ & 34.5 & 60.1 & 0 & 100 & 100 & 1124.4 & 1943 & 0.74 & 12 \\
\hline $\begin{array}{l}\text { Sierra de } \\
\text { Manantlan }\end{array}$ & 42.8 & 121.8 & 53.4 & 46.58 & $\begin{array}{r}42.9 \\
5\end{array}$ & 1395.8 & 4441 & 0.67 & 29 \\
\hline $\begin{array}{l}\text { Sierra del } \\
\text { Abra- } \\
\text { Tanchipa }\end{array}$ & 161.8 & 348.0 & 0 & 100 & 100 & 214.6 & 279 & 0.68 & 27 \\
\hline Sierra Gorda & 29.1 & 50.2 & 0 & 100 & 100 & 3835.7 & 5347 & 0.85 & 2 \\
\hline
\end{tabular}




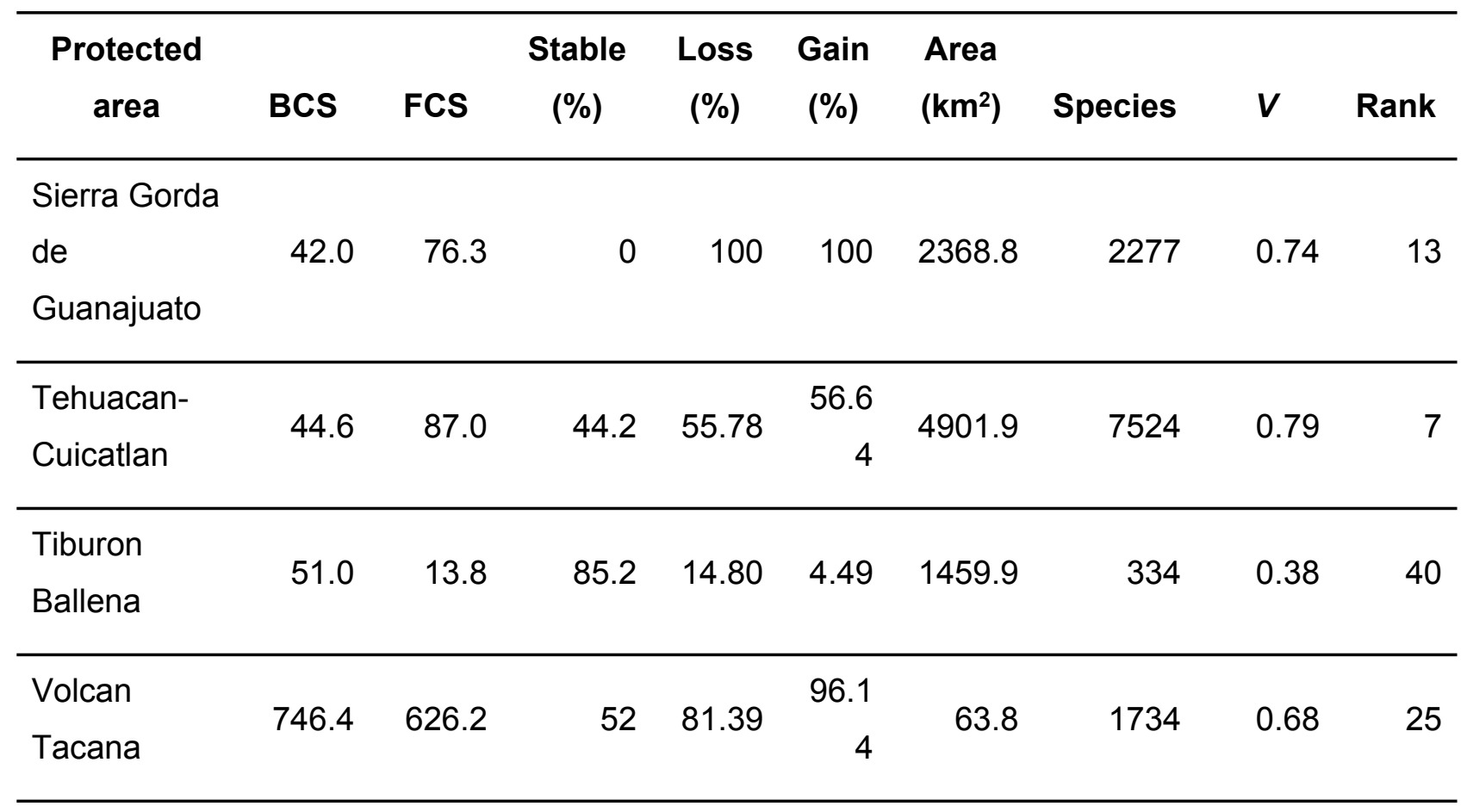




\section{Appendix 4}

For each taxonomic group in Mexico, the number of records, and the number of species and families represented, are given in Table A4.1. The number of species varied across the 40 protected areas. On average, protected areas had $2398 \pm$ 1759 species recorded (mean \pm standard deviation). The highest number of species was found in Tehuacán-Cuicatlán (Oaxaca-Puebla; 7524 species) and the lowest in Sierra del Abra-Tanchipa (San Luis Potosí; 279 species) (Table A4.2, Figure A4). Some taxonomic groups are not recorded at all within the studied network of protected areas. Amphibians and reptiles were the most underrepresented groups with $20 \pm 21$ species and $56 \pm 38$ species, respectively. Records of amphibians and fungi were absent in three and eight protected areas, respectively. Also, we found only one amphibian species recorded in Ojo de Liebre (Baja California Sur) and Lacan-Tun (Chiapas), and one fungi species in LacanTun. In contrast, vascular plants had the highest number of species (1267 \pm 1168$)$, followed by arthropods (383 \pm 403$)$. Tehuacán-Cuicatlán had the highest number of records per individual group, in contrast to Isla Guadalupe (Baja California) and Isla San Pedro Mártir (Sonora), which had fewest records (Table A4.3). 
Table A4.1. Number of families, species, and occurrence records for each taxonomic group.

\begin{tabular}{lccc}
\hline Taxonomic group & No. families & No. species & No. records \\
\hline Amphibians & 22 & 743 & 179,886 \\
\hline Arthropods & 1071 & 17,161 & 600,135 \\
\hline Birds & 63 & 2281 & 883,093 \\
\hline Mammals & 50 & 1408 & 64,905 \\
\hline Reptiles & 45 & 2159 & 250,666 \\
\hline Fungi & 352 & 6674 & 90,653 \\
\hline Vascular plants & 566 & 45,767 & $1,516,873$ \\
\hline
\end{tabular}




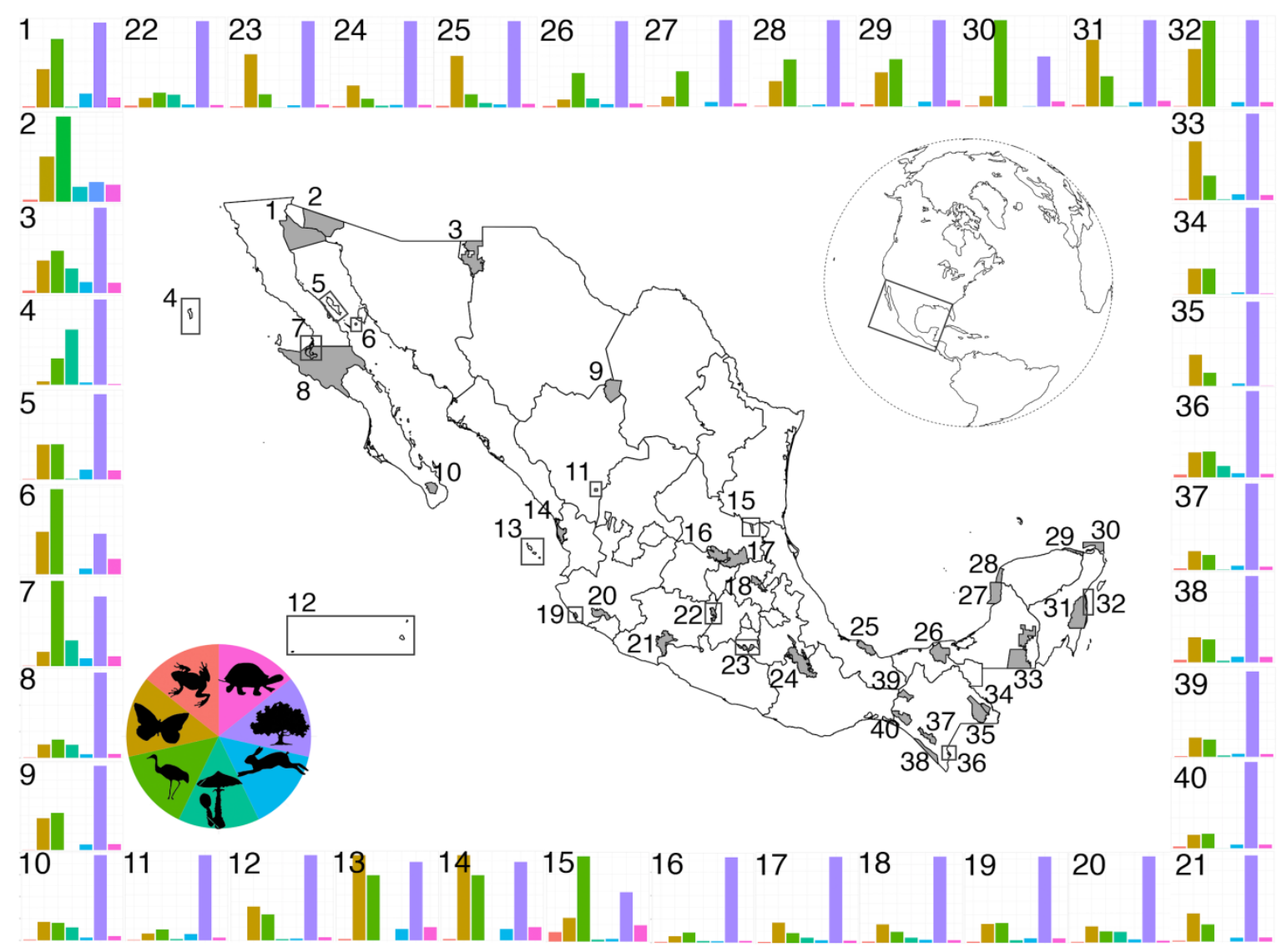

Figure A4. Location of the 40 protected areas of Mexico and histograms indicating the number of species recorded of seven major taxonomic groups within three kingdoms: 1) vascular plants (Tracheophytes); 2) fungi; and 3) animals (amphibians, arthropods, birds, mammals, and reptiles) (see details on Table A4.3). Protected areas are indicated as follows: 1) Alto Golfo de California y delta del río Colorado; 2) El Pinacate y Gran Desierto de Altar; 3) Janos; 4) Isla Guadalupe; 5) Bahia de los Angeles, canales de Ballenas y de Salsipuedes; 6) Isla San Pedro Mártir; 7) Complejo lagunar Ojo de Liebre; 8) El Vizcaíno; 9) Mapimí; 10) Sierra de la Laguna; 11) La Michilía; 12) Archipielago de Revillagigedo; 13) Islas Marias; 14) Marismas Nacionales; 15) Sierra del Abra-Tanchipa; 16) Sierra Gorda de Guanajuato; 17) Sierra Gorda; 18) Barranca de Metztitlán; 19) Chamela- 
Cuixmala; 20) Sierra de Manantlán; 21) Zicuirán Infiernillo; 22) Mariposa Monarca; 23) Sierra de Huautla; 24) Tehuacán-Cuicatlán; 25) Los Tuxtlas; 26) Pantanos de Centla; 27) Los Petenes; 28) Ría Celestún; 29) Ría Lagartos; 30) Tiburón Ballena; 31) Sian Ka'an; 32) Arrecifes de Sian Ka'an; 33) Calakmul; 34) Lacan-Tún; 35) Montes Azules; 36) Volcán Tacaná; 37) El Triunfo; 38) La Encrucijada; 39) Selva el Ocote; and 40) La Sepultura. 
Table A4.2. Mean and standard deviation (SD), maximum (Max) and minimum (Min) number of species reported for each taxonomic group in 40 protected areas of Mexico. Names in parentheses indicate the reserves where those values were found.

\begin{tabular}{|c|c|c|c|c|}
\hline $\begin{array}{l}\text { Taxonomic } \\
\text { group }\end{array}$ & Mean & SD & Max & Min \\
\hline Amphibia & 20 & 21 & $\begin{array}{c}87 \\
\text { (Tehuacán-Cuicatlán) }\end{array}$ & $\begin{array}{c}0 \\
\text { (Archipiélago de } \\
\text { Revillagigedo, Isla } \\
\text { Guadalupe, Isla San } \\
\text { Pedro Mártir) }\end{array}$ \\
\hline Arthropoda & 383 & 403 & $\begin{array}{c}1867 \\
\text { (Los Tuxtlas) }\end{array}$ & $\begin{array}{c}9 \\
\text { (Isla Guadalupe) }\end{array}$ \\
\hline Aves & 298 & 131 & $\begin{array}{c}530 \\
\text { (Tehuacán-Cuicatlán) }\end{array}$ & $\begin{array}{c}44 \\
\text { (Isla San Pedro Mártir) }\end{array}$ \\
\hline Mammalia & 59 & 44 & $\begin{array}{c}162 \\
\text { (Tehuacán-Cuicatlán) }\end{array}$ & (Tiburón Ballena) \\
\hline Reptilia & 56 & 38 & $\begin{array}{c}161 \\
\text { (Tehuacán-Cuicatlán) }\end{array}$ & $\begin{array}{c}2 \\
\text { (Isla Guadalupe) }\end{array}$ \\
\hline Fungi & 64 & 89 & $\begin{array}{c}366 \\
\text { (Sierra de Manantlán) }\end{array}$ & $\begin{array}{c}0 \\
\text { (Arrecifes de Sian Ka'an, } \\
\text { Isla San Pedro Mártir, } \\
\text { Islas Marías, Mapimí, } \\
\text { Marismas Nacionales, } \\
\text { los Petenes, Tiburón } \\
\text { Ballena, Zicuirán } \\
\text { Infiernillo) }\end{array}$ \\
\hline Tracheophyte & 1267 & 1168 & $\begin{array}{c}5161 \\
\text { (Tehuacán-Cuicatlán) }\end{array}$ & $\begin{array}{c}21 \\
\text { (Isla San Pedro Mártir) }\end{array}$ \\
\hline
\end{tabular}


Table A4.3. Names and locations by state of 40 protected areas of Mexico. The total number of species and records of seven taxonomic groups (amphibians, Amph; arthropods, Arthr; birds; mammals, Mamm; reptiles, Rept; fungi; and plants) were obtained from the Global Biodiversity Information Facility (GBIF, http://www.gbif.org).

\begin{tabular}{|c|c|c|c|c|c|c|c|c|c|c|}
\hline \multirow[t]{2}{*}{ Reserve } & \multirow[t]{2}{*}{ State } & \multirow[t]{2}{*}{ Total no. species } & \multicolumn{8}{|c|}{ No. of species } \\
\hline & & & Records & Amph & Arthr & Birds & Mamm & Rept & Fungi & Plants \\
\hline $\begin{array}{l}\text { Alto Golfo } \\
\text { de } \\
\text { California y } \\
\text { delta del } \\
\text { río } \\
\text { Colorado }\end{array}$ & $\begin{array}{c}\text { Baja California, } \\
\text { Sonora }\end{array}$ & 937 & 1,009 & 4 & 166 & 297 & 60 & 43 & 3 & 368 \\
\hline $\begin{array}{c}\text { Archipiélag } \\
\text { o de } \\
\text { Revillagige } \\
\text { do }\end{array}$ & Colima & 587 & 7,515 & 0 & 131 & 101 & 7 & 12 & 5 & 331 \\
\hline $\begin{array}{l}\text { Arrecifes } \\
\text { de Sian } \\
\text { Ka'an }\end{array}$ & Quintana Roo & 864 & 14,642 & 2 & 208 & 310 & 16 & 16 & 0 & 312 \\
\hline
\end{tabular}




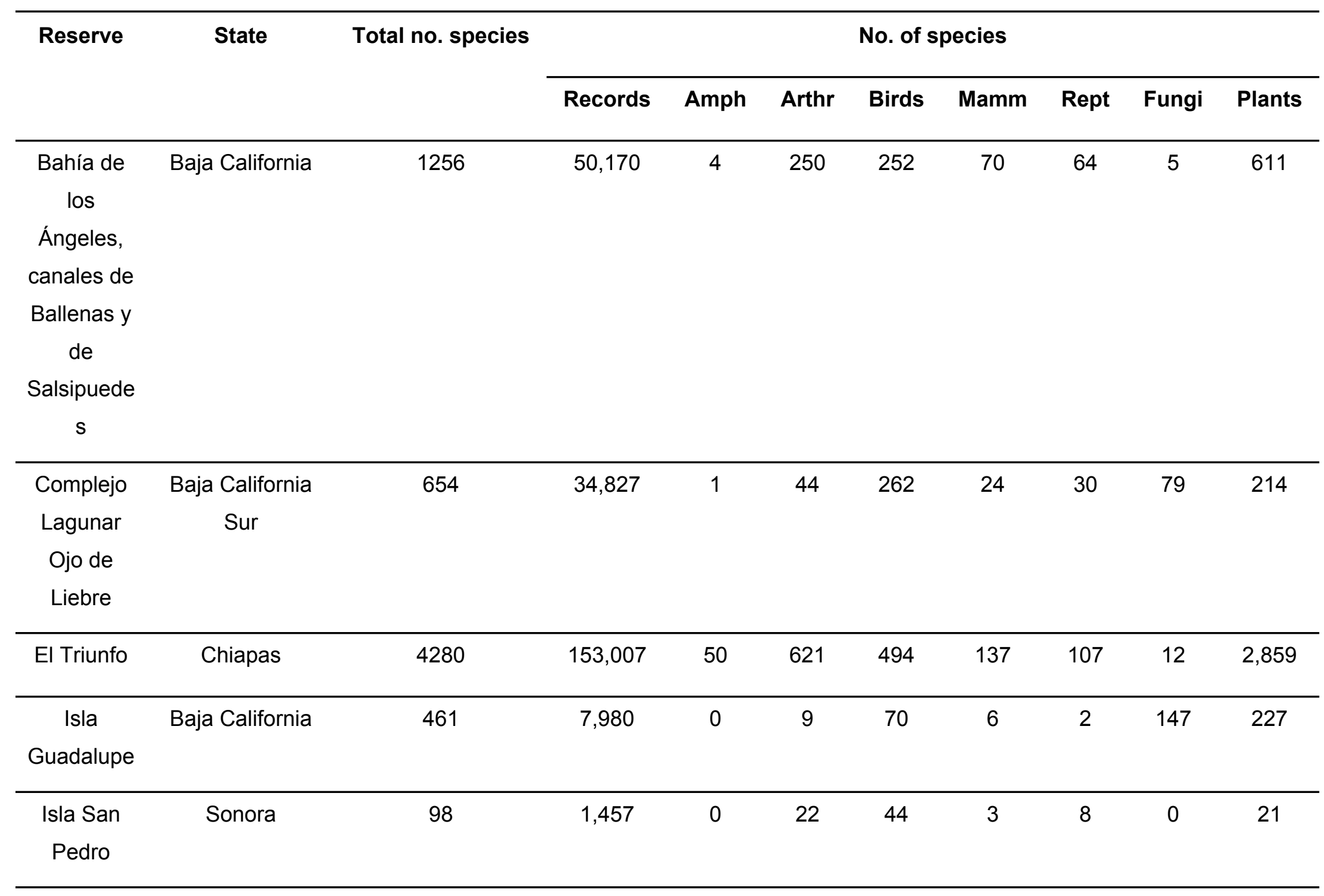




\begin{tabular}{|c|c|c|c|c|c|c|c|c|c|c|}
\hline \multirow[t]{2}{*}{ Reserve } & \multirow[t]{2}{*}{ State } & \multirow[t]{2}{*}{ Total no. species } & \multicolumn{8}{|c|}{ No. of species } \\
\hline & & & Records & Amph & Arthr & Birds & Mamm & Rept & Fungi & Plants \\
\hline \multicolumn{11}{|l|}{ Mártir } \\
\hline $\begin{array}{l}\text { Islas } \\
\text { Marías }\end{array}$ & Nayarit & 559 & 6,351 & 3 & 187 & 143 & 25 & 29 & 0 & 172 \\
\hline $\begin{array}{c}\text { La } \\
\text { Sepultura }\end{array}$ & Chiapas & 4056 & 45,300 & 60 & 442 & 480 & 121 & 122 & 4 & 2,827 \\
\hline Mapimí & $\begin{array}{c}\text { Chihuahua, } \\
\text { Coahuila, } \\
\text { Durango }\end{array}$ & 963 & 16,672 & 7 & 185 & 215 & 37 & 39 & 0 & 480 \\
\hline $\begin{array}{l}\text { Marismas } \\
\text { Nacionales }\end{array}$ & Nayarit & 825 & 23,085 & 18 & 147 & 358 & 47 & 50 & 0 & 205 \\
\hline $\begin{array}{l}\text { Pantanos } \\
\text { de Centla }\end{array}$ & Tabasco & 1424 & 22,498 & 15 & 78 & 334 & 33 & 38 & 88 & 838 \\
\hline $\begin{array}{c}\text { Reserva } \\
\text { de la } \\
\text { Biosfera }\end{array}$ & Jalisco & 1967 & 36,781 & 16 & 270 & 283 & 64 & 63 & 36 & 1,235 \\
\hline
\end{tabular}




\begin{tabular}{|c|c|c|c|c|c|c|c|c|c|c|}
\hline \multirow[t]{2}{*}{ Reserve } & \multirow[t]{2}{*}{ State } & \multirow[t]{2}{*}{ Total no. species } & \multicolumn{8}{|c|}{ No. of species } \\
\hline & & & Records & Amph & Arthr & Birds & Mamm & Rept & Fungi & Plants \\
\hline \multicolumn{11}{|l|}{$\begin{array}{l}\text { Chamela- } \\
\text { Cuixmala }\end{array}$} \\
\hline $\begin{array}{c}\text { Reserva } \\
\text { de la } \\
\text { biosfera de } \\
\text { Calakmul }\end{array}$ & Campeche & 3099 & 115,329 & 24 & 987 & 410 & 96 & 84 & 10 & 1,455 \\
\hline $\begin{array}{c}\text { Reserva } \\
\text { de la } \\
\text { Biósfera de } \\
\text { la } \\
\text { Barranca } \\
\text { de } \\
\text { Metztitlán }\end{array}$ & Hidalgo & 3223 & 25,050 & 33 & 469 & 281 & 77 & 65 & 130 & 2,201 \\
\hline $\begin{array}{c}\text { Reserva } \\
\text { de la } \\
\text { biosfera de }\end{array}$ & $\begin{array}{c}\text { México, } \\
\text { Michoacan }\end{array}$ & 2194 & 33,300 & 31 & 161 & 250 & 50 & 42 & 215 & 1,445 \\
\hline
\end{tabular}




\begin{tabular}{|c|c|c|c|c|c|c|c|c|c|c|}
\hline \multirow[t]{2}{*}{ Reserve } & \multirow[t]{2}{*}{ State } & \multirow[t]{2}{*}{ Total no. species } & \multicolumn{8}{|c|}{ No. of species } \\
\hline & & & Records & Amph & Arthr & Birds & Mamm & Rept & Fungi & Plants \\
\hline \multicolumn{11}{|l|}{ la } \\
\hline \multicolumn{11}{|l|}{ Mariposa } \\
\hline $\begin{array}{c}\text { Reserva } \\
\text { de la }\end{array}$ & Campeche & 1098 & 9,768 & 7 & 78 & 276 & 36 & 25 & 0 & 676 \\
\hline \multirow{2}{*}{\multicolumn{11}{|c|}{$\begin{array}{l}\text { biosfera de } \\
\text { los }\end{array}$}} \\
\hline & & & & & & & & & & \\
\hline \multicolumn{11}{|l|}{ biosfera el } \\
\hline \multicolumn{11}{|l|}{ Pinacate y } \\
\hline \multicolumn{11}{|l|}{ Gran } \\
\hline \multirow{2}{*}{\multicolumn{11}{|c|}{$\begin{array}{l}\text { Desierto } \\
\text { de Altar }\end{array}$}} \\
\hline & & & & & & & & & & \\
\hline Reserva & Baja California & 2619 & 71,360 & 8 & 253 & 347 & 69 & 74 & 248 & 1,227 \\
\hline de la & Sur & & & & & & & & & \\
\hline
\end{tabular}




\begin{tabular}{|c|c|c|c|c|c|c|c|c|c|c|}
\hline \multirow[t]{2}{*}{ Reserve } & \multirow[t]{2}{*}{ State } & \multirow[t]{2}{*}{ Total no. species } & \multicolumn{8}{|c|}{ No. of species } \\
\hline & & & Records & Amph & Arthr & Birds & Mamm & Rept & Fungi & Plants \\
\hline \multicolumn{11}{|l|}{ biosfera } \\
\hline \multicolumn{11}{|l|}{ EIVizcaíno } \\
\hline $\begin{array}{c}\text { Reserva } \\
\text { de la }\end{array}$ & Chihuahua & 1427 & 15,744 & 16 & 223 & 290 & 75 & 70 & 168 & 585 \\
\hline \multicolumn{11}{|l|}{ Biosfera } \\
\hline \multicolumn{11}{|l|}{ Janos } \\
\hline $\begin{array}{c}\text { Reserva } \\
\text { de la }\end{array}$ & Chiapas & 3196 & 55,254 & 56 & 536 & 489 & 121 & 118 & 37 & 1,839 \\
\hline \multicolumn{11}{|l|}{ Biósfera La } \\
\hline \multicolumn{11}{|l|}{ Encrucijad } \\
\hline \multicolumn{11}{|l|}{$a$} \\
\hline $\begin{array}{c}\text { Reserva } \\
\text { de la }\end{array}$ & Durango & 501 & 1745 & 2 & 30 & 48 & 28 & 12 & 6 & 375 \\
\hline \multicolumn{11}{|l|}{ Biosfera La } \\
\hline Michilía & & & & & & & & & & \\
\hline
\end{tabular}




\begin{tabular}{|c|c|c|c|c|c|c|c|c|c|c|}
\hline \multirow[t]{2}{*}{ Reserve } & \multirow[t]{2}{*}{ State } & \multirow[t]{2}{*}{ Total no. species } & \multicolumn{8}{|c|}{ No. of species } \\
\hline & & & Records & Amph & Arthr & Birds & Mamm & Rept & Fungi & Plants \\
\hline $\begin{array}{c}\text { Reserva } \\
\text { de la } \\
\text { Biosfera } \\
\text { Lacan-Tun }\end{array}$ & Chiapas & 1344 & 5,897 & 1 & 245 & 245 & 18 & 6 & 1 & 828 \\
\hline $\begin{array}{c}\text { Reserva } \\
\text { de la } \\
\text { Biosfera } \\
\text { Los } \\
\text { Tuxtlas }\end{array}$ & Veracruz & 5945 & 151,657 & 63 & 1,867 & 478 & 114 & 134 & 167 & 3,122 \\
\hline $\begin{array}{c}\text { Reserva } \\
\text { de la } \\
\text { Biósfera } \\
\text { Montes } \\
\text { Azules }\end{array}$ & Chiapas & 4785 & 123,172 & 42 & 1,108 & 509 & 155 & 81 & 29 & 2,861 \\
\hline $\begin{array}{c}\text { Reserva } \\
\text { de la } \\
\text { biosfera }\end{array}$ & Chiapas & 3697 & 45,849 & 46 & 547 & 493 & 110 & 102 & 65 & 2,334 \\
\hline
\end{tabular}




\begin{tabular}{|c|c|c|c|c|c|c|c|c|c|c|}
\hline \multirow[t]{2}{*}{ Reserve } & \multirow[t]{2}{*}{ State } & \multirow[t]{2}{*}{ Total no. species } & \multicolumn{8}{|c|}{ No. of species } \\
\hline & & & Records & Amph & Arthr & Birds & Mamm & Rept & Fungi & Plants \\
\hline \multicolumn{11}{|l|}{ Selva } \\
\hline \multicolumn{11}{|l|}{ ElOcote } \\
\hline $\begin{array}{c}\text { Reserva } \\
\text { de la }\end{array}$ & Colima, Jalisco & 4441 & 51,768 & 25 & 551 & 383 & 108 & 64 & 366 & 2,944 \\
\hline \multicolumn{11}{|l|}{ Biosfera } \\
\hline \multicolumn{11}{|l|}{ Sierra de } \\
\hline \multicolumn{11}{|l|}{ Manantlán } \\
\hline $\begin{array}{c}\text { Reserva } \\
\text { de la }\end{array}$ & Querétaro & 5347 & 65,958 & 41 & 854 & 414 & 116 & 101 & 224 & 3,597 \\
\hline \multicolumn{11}{|l|}{ biosfera } \\
\hline \multicolumn{11}{|l|}{ Sierra } \\
\hline \multicolumn{11}{|l|}{ Gorda } \\
\hline $\begin{array}{c}\text { Reserva } \\
\text { de la }\end{array}$ & Oaxaca, Puebla & 7524 & 143,849 & 87 & 1,316 & 530 & 162 & 161 & 107 & 5,161 \\
\hline biosfera & & & & & & & & & & \\
\hline Tehuacán- & & & & & & & & & & \\
\hline
\end{tabular}




\begin{tabular}{|c|c|c|c|c|c|c|c|c|c|c|}
\hline \multirow[t]{2}{*}{ Reserve } & \multirow[t]{2}{*}{ State } & \multirow[t]{2}{*}{ Total no. species } & \multicolumn{8}{|c|}{ No. of species } \\
\hline & & & Records & Amph & Arthr & Birds & Mamm & Rept & Fungi & Plants \\
\hline \multicolumn{11}{|l|}{ Cuicatlán } \\
\hline $\begin{array}{c}\text { Reserva } \\
\text { de la }\end{array}$ & Quintana Roo & 334 & 5,115 & 2 & 23 & 188 & 1 & 11 & 0 & 109 \\
\hline \multicolumn{11}{|l|}{ Biosfera } \\
\hline \multicolumn{11}{|l|}{ Tiburón } \\
\hline \multicolumn{11}{|l|}{ Ballena } \\
\hline $\begin{array}{c}\text { Reserva } \\
\text { de la }\end{array}$ & Michoacán & 1781 & 38,701 & 12 & 357 & 217 & 49 & 52 & 0 & 1,094 \\
\hline \multicolumn{11}{|l|}{ biosfera } \\
\hline \multicolumn{11}{|l|}{ Zicuirán } \\
\hline \multicolumn{11}{|l|}{ Infiernillo } \\
\hline Ría & Campeche, & 1166 & 29,111 & 5 & 178 & 330 & 15 & 28 & 5 & 605 \\
\hline Celestún & Yucatan & & & & & & & & & \\
\hline Ría & Yucatán & 1453 & 83,183 & 18 & 274 & 379 & 39 & 50 & 2 & 691 \\
\hline Lagartos & & & & & & & & & & \\
\hline
\end{tabular}




\begin{tabular}{|c|c|c|c|c|c|c|c|c|c|c|}
\hline \multirow[t]{2}{*}{ Reserve } & \multirow[t]{2}{*}{ State } & \multirow[t]{2}{*}{ Total no. species } & \multicolumn{8}{|c|}{ No. of species } \\
\hline & & & Records & Amph & Arthr & Birds & Mamm & Rept & Fungi & Plants \\
\hline Sian Ka'an & Quintana Roo & 2688 & 81,973 & 25 & 916 & 416 & 60 & 78 & 7 & 1,186 \\
\hline $\begin{array}{l}\text { Sierra de } \\
\text { Huautla }\end{array}$ & Morelos & 2308 & 33,855 & 16 & 772 & 192 & 32 & 42 & 2 & 1,252 \\
\hline $\begin{array}{l}\text { Sierra de } \\
\text { la Laguna }\end{array}$ & $\begin{array}{c}\text { Baja California } \\
\text { Sur }\end{array}$ & 1943 & 29,892 & 9 & 253 & 240 & 38 & 58 & 178 & 1,167 \\
\hline $\begin{array}{c}\text { Sierra del } \\
\text { Abra- } \\
\text { Tanchipa }\end{array}$ & San Luis Potosí & 279 & 778 & 14 & 35 & 126 & 4 & 24 & 3 & 73 \\
\hline $\begin{array}{c}\text { Sierra } \\
\text { Gorda de } \\
\text { Guanajuat } \\
\quad \text { o }\end{array}$ & Guanajuato & 2277 & 12,827 & 16 & 136 & 212 & 29 & 34 & 33 & 1,817 \\
\hline $\begin{array}{l}\text { Volcán } \\
\text { Tacaná }\end{array}$ & Chiapas & 1734 & 16,968 & 31 & 273 & 282 & 46 & 39 & 124 & 939 \\
\hline
\end{tabular}

